Discussion

Papers
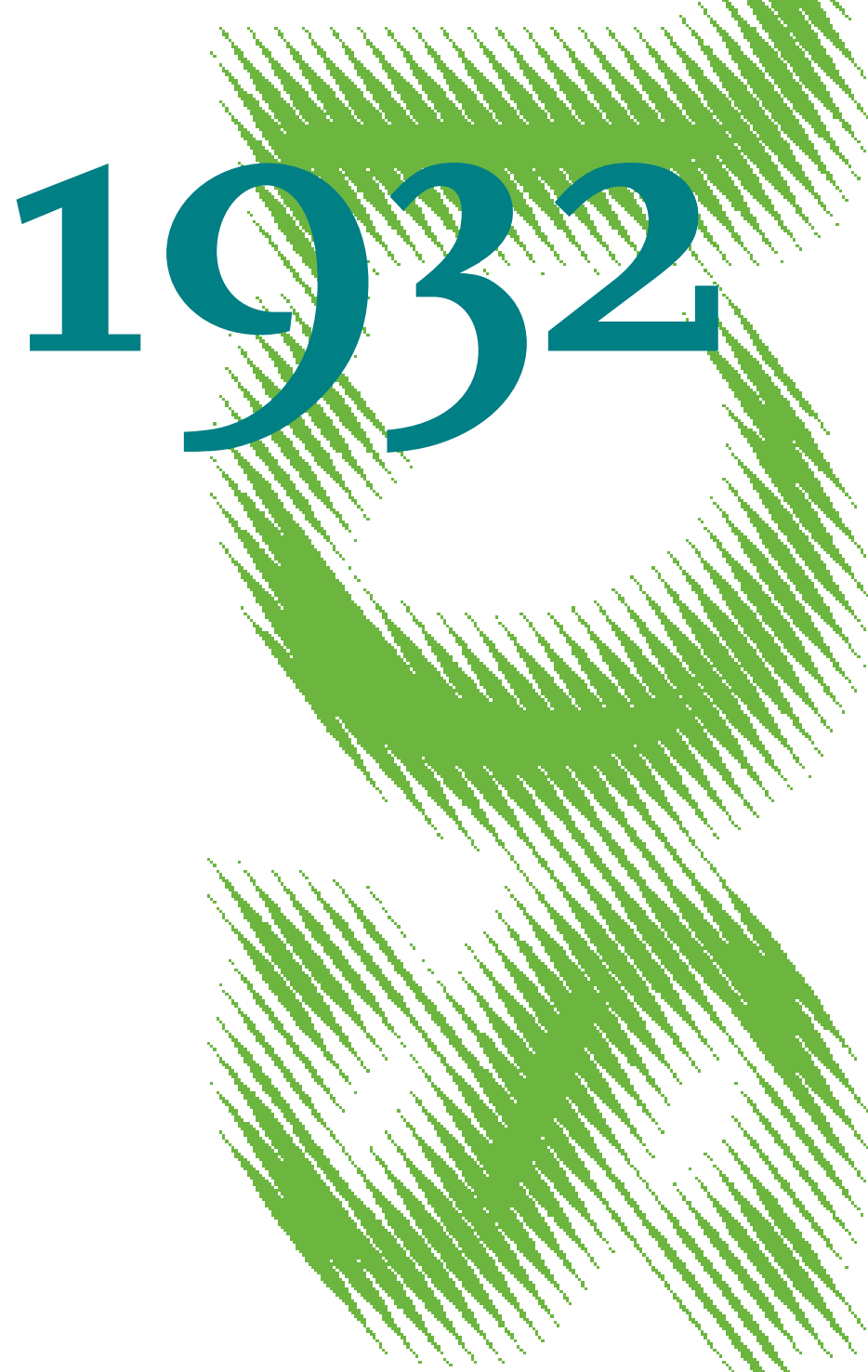

The Importance of Mothers-in-Law's Employment for Their Daughter-in-Law's Labour Market Outcomes in West-Germany Results and Mechanisms 
Opinions expressed in this paper are those of the author(s) and do not necessarily reflect views of the institute.

IMPRESSUM

(C) DIW Berlin, 2021

DIW Berlin

German Institute for Economic Research

Mohrenstr. 58

10117 Berlin

Tel. +49 (30) $89789-0$

Fax +49 (30) $89789-200$

http://www.diw.de

ISSN electronic edition 1619-4535

Papers can be downloaded free of charge from the DIW Berlin website:

http://www.diw.de/discussionpapers

Discussion Papers of DIW Berlin are indexed in RePEc and SSRN:

http://ideas.repec.org/s/diw/diwwpp.html

http://www.ssrn.com/link/DIW-Berlin-German-Inst-Econ-Res.html 


\title{
The importance of mothers-in-law's employment for their daughter-in-law's labour market outcomes in West Germany: results and mechanisms
}

\author{
Sophia Schmitz $^{1} \quad$ C. Katharina Spiess ${ }^{1,2^{*}}$ \\ ${ }^{1}$ DIW Berlin - German Institute for Economic Research \\ ${ }^{2}$ Freie Universität Berlin
}

* Corresponding Author: C. Katharina Spiess (kspiess@diw.de)

February 2021

Acknowledgements: We thank Natalia Danzer, Felix Weinhardt, Vaishu Zambre, and participants of the DIW-Graduate Center Summer Workshop for valuable comments and suggestions. Moreover, we thank Adam Lederer for very helpful editorial assistance. 


\begin{abstract}
Social norms have been put forward as prominent explanations for the changing labour supply decisions of women. This paper studies the intergenerational formation of these norms, examining how they affect subsequent female labour supply decisions, taking into account not only the early socialization of women but also that of their partner. Using large representative panel data sets from West Germany, results suggest that women with partners who grew up with a working mother are more likely to participate in the labour force, work longer hours, and earn higher labour income. Our study can assess a variety of potential mechanisms for this intergenerational link. It cannot be explained by other confounding patterns. We find no evidence that this finding reflects assortative mating; rather, analysis suggests that the partner's preferences play a decisive role for the labour supply decision of partnered women. Our results suggest that policy measures supporting the labour force participation of today's mothers will increase the female labour force participation of the next generation.
\end{abstract}

JEL codes: J22, Z13, J16

Keywords: social norms, labour supply, gender, Germany 


\section{Introduction}

The role of women in many Western industrialized countries has changed fundamentally since the 1960s. One of the most dramatic shifts is the vast increase in female labour force participation, especially among women with children. For example, in Germany, as of 2015, 73 percent of women aged between 16 and 65 (73 percent) worked outside the home, compared with 47 percent in 1960 (Federal Statistical Office - Statistisches Bundesamt; 2017). Yet, in Germany, the full-time participation of women remains low, especially among mothers, with large regional differences in participation persisting. The literature provides various reasons for the rise in female labour force participation, which depends on the time period of the observed increase. Such explanations include the introduction of new consumer durables, the development of contraceptive technologies, an extension of the service sector, an increase in the availability of formal child care, skill biased technological changes, changes in the wage and labour market structure, as well as other demand side related factors (e.g. Galor and Weil; 1996; Goldin; 1990; Goldin and Katz; 2002; Greenwood et al.; 2005; Fernández et al.; 2004; Knowles; 2012; Attanasio et al.; 2008; Olivetti; 2006).

In the economic literature a relatively new, rapidly growing, strand of the literature emphasizes the importance of social norms, especially of gender identity norms, in explaining this transformation and the observed patterns. This strand of the economic literature builds on, and adds to, the various existing studies in other social sciences, such as political science and, in particular, sociology (e.g. Inglehart and Norris; 2003; Bittman et al.; 2003; Sullivan; 2006; Charles and Grusky; 2004; Coltrane; 2000). ${ }^{1}$ Many of these studies underline that value changes have transformed gender roles on issues like female

\footnotetext{
${ }^{1}$ This literature addresses different aspects, such as differences among societies, effects of housework behaviour, occupational segregation or "doing gender."
} 
labour force participation. ${ }^{2}$ While most of these studies emphasize the importance of gender identity norms of a society as a whole or a woman's own gender identity norms and attitudes on her labour supply decision, there is less research on how gender norms of peers and other family member matter. This is the focus of our study.

So far, few studies emphasize that, with respect to gender identity norms, there are important social learning effects, namely from peers (e.g. Fernández; 2011; Olivetti et al.; forthcoming) and the family (e.g. Nicoletti et al.; 2019). ${ }^{3}$ Even fewer studies focus explicitly on intergenerational links, suggesting that the behaviour of the older generation influences the norms and attitudes of the younger generation and, thus, their subsequent labour market behaviour. This literature examines intergenerational correlations between the working status of parents during childhood and subsequent labour supply decisions during adulthood in a quantitative way. Fernández et al. (2004), in their pioneering study on this topic, argue that a significant determinant of the rise in female labour force participation rates among US women was the presence of a new type of man, namely one that was brought up by a working mother. Relatedly, Farre and Vella (2013) show that mothers' gender role attitudes are correlated with their children's attitudes and labour force participation. Using a US-Survey, they also find such correlations between mothers and daughters-in-law, specifically, there is an association between the attitudes of sons in their youth and their wives' labour supply as adults. ${ }^{4}$ Significant and robust correlations between the labour supply of married women and their mothers-in-law are also documented for Switzerland (Bütikofer; 2013). Using Danish data, Kleven, Landais, Posch, Steinhauer and Zweimüller (2019) find evidence for a link between labour market child penalties and the work history of maternal grandparents, but not for paternal grandpar-

\footnotetext{
${ }^{2}$ There is also a growing literature on policy feedback processes and work-care cultures, thus examining the effect of policy changes that are simultaneously the results and the drivers of changes in gender norms (e.g. Gangl and Ziefle; 2009; Kremer; 2007; Zoch and Schober; 2018; Unterhofer and Wrohlich; 2017).

${ }^{3}$ Kleven and Landais (2017) are an example of an economic study which analyses the economic development of socities and the role of gender norms.

${ }^{4}$ For daughters, the association between their own attitudes and adult work outcomes is weaker and seems to operate through the educational channel.
} 
ents. Their findings refer to the idea that a woman's preference over family and career is shaped by the gender roles she is exposed to during her childhood. Kawaguchi and Miyazaki (2009) do not find such associations for parents in Japan.

We add to this later literature by analysing intergenerational correlations between various labour market outcomes of women 25 to 55 years of age and the labour market participation of her mother and mother-in-law. Compared to the few existing studies, we use large and representative data sets that allow us to learn more about various mechanisms for the intergenerational links we find. Other studies use less detailed data. We focus our study on females in West Germany.

Our results for West Germany suggest that women with partners who grew up with a working mother are more likely to participate in the labour force, work longer hours, and, consequently, have higher labour income. This holds when controlling for various background characteristics and local labour market conditions. The intergenerational labour force participation link is comparable with existing estimates on samples for the US (Fernández et al.; 2004; Farre and Vella; 2013) and Switzerland (Bütikofer; 2013), but not comparable to results of Kleven, Landais and Søgaard (2019), who analyse a more gender equal Scandinavian society. Moreover, just like in the US and Switzerland, we document that the working status of the mother-in-law is more predictive than the working status of the woman's own mother for female labour supply.

However, unlike existing studies, we assess a variety of potential mechanisms for this intergenerational link using large and rich panel data sets, covering not only married but also cohabiting women living in West Germany. This shows that men who grew up with a working mother develop different social norms and attitudes toward working women than other men, measured by various statements concerning the compatibility of work and motherhood. However, they do not spend more time on unpaid work, such as housework or childrearing, and, thus, do not contribute to lowering the double burden of their working partners. In addition, we assess whether the intergenerational correlation 
reflects assortative mating in other unobserved characteristics or can be interpreted as evidence that the partner's preferences determine the labour supply decision of women. To distinguish between these channels, we use additional data on (single) women and exploit the panel structure of our main dataset, thus allowing us to observe the same women in different partnerships. In addition, we examine heterogeneities by different background characteristics that reflect relative bargaining positions within the household. To analyse effect heterogeneiy is important as women are heterogeneous in their preferences and priorities on family-employment conflicts (e.g. Hakim; 2000, 2002).

There are three key findings: First, the labour supply decision of women is not correlated with gender norms of future partners. Second, even when taking into account individual fixed effects, i.e. when exploiting variation that comes from women switching their partner, having a working mother-in-law is as significant predictor for various labour market outcomes. Third, heterogeneity analysis suggests that the relationship is strongest in partnerships where the woman has less bargaining power and for couples where we would expect norms to play a more significant role, like in rural areas. Taken together, this indicates that the strong intergenerational link between the labour supply of women and their mother-in-law is not an outcome of assortative mating but results from gender-specific processes in the formation of preferences during adolescence and subsequent household behaviour, where the male decision maker plays a decisive role for the outcome. ${ }^{5}$ Using much larger and richer panel datasets then previous studies allows us to rule out a variety of alternative explanations. For example, we can rule out that the correlation reflects systematic recall error or variation in local culture, peer effects, or other regional labour market conditions that are more prone to women's labour force participation, rather than the direct impact of mother's and mother-in-law's labour force participation. In addition, the panel-structure of our main data allows us to study how the

\footnotetext{
${ }^{5}$ Iversen and Rosenbluth $(2006,18)$ point out that this aspect is a particular promising one, namely changing gender roles in childhood socialization.
} 
correlation evolves over the life-cycle of women; i.e. allowing us to get a sense when norms might kick in. Finally, we note that the intergenerational correlations in female labour supply could be confounded by mothers who think that women should work and thus support their son's family with grand-parental childcare; thus, enabling both partners to work. To exclude this channel, we document that the correlation between having a working mother and female labour force participation is unchanged when the mother-in-law is deceased or does not live in proximity.

This study also contributes to the literature studying preferences and identity formations. The psychological socialization literature (Bandura; 1977) and economic literature on preference formation and transmission (e.g. Bisin and Verdier; 2000) highlight the importance of childhood and, in particular, adolescence, as social and gender norms are established earlier in life while children are exposed mainly to their parents as role models. ${ }^{6}$ The "gender intensification hypothesis" is used in psychology to explain an array of situations whereby gender difference emerge or intensify during adolescence (Hill and Lynch; 1983). ${ }^{7}$

\section{Institutional Context}

The focus of this study on West Germany is of particular interest for several reasons: The West German society is characterized by a gendered division of paid und unpaid work, where most men are employed full-time and women work part-time jobs while still retaining the majority of caregiving responsibilities (e.g. Rosenfeld et al.; 2004). Although

\footnotetext{
${ }^{6}$ Assessing the joint dynamics of culture and female labour force participation on a macro level, two recent papers by Fogli and Veldkamp (2011) and Fernández (2013) model work and cultural change as a learning process where women learn about the effects and long-run costs of maternal employment, from their parents and by observing employed women nearby.

${ }^{7}$ More broadly, this study also contributes to the literature that stress the quantitative importance of social norms. For example, using the "epidemiological" approach (see Fernández; 2011, for an overview), many studies find that a significant portion of variance in work or fertility behaviour of second generation immigrants can be accounted for by variables that reflect the cultural norms in the country-of-ancestry (e.g. Fernandez and Fogli; 2009; Antecol; 2000).
} 
the overall female labour force participation rate in Germany is around the EU average, the maternal employment rate is relatively low, particularly with respect to maternal fulltime employment or the employment of mothers with three or more dependent children (OECD; 2019). Thus, in West Germany, women's engagement in paid work strongly depends on the presence and age of children, more than in many other Western countries (e.g. Rosenfeld et al.; 2004). Compared to other non-German speaking countries, West Germany exhibits the largest child penalties with respect to labour market outcomes of women despite being characterised by a very low realized fertility (e.g. Kleven, Landais and Søgaard; 2019). This is a result of a persistent cultural tradition of subsidiarity in which parenthood and care work are viewed in highly privatized terms, relative to other European societies where childbearing is viewed more as a collective responsibility.

Germany has a generous paid maternal leave system allowing mothers to take a three years long job protected leave (e.g. Ondrich et al.; 2003). For many decades, day care was mainly available for preschoolers, but only part-time. Most schools were part-timeschools and children ate lunch at home. These policies were associated with long labour force interruptions of women after birth. Nevertheless, Germany has made several changes since the turn of the century: it reformed its paid parental leave policies, increased the availability of daycare for children younger than three, provided more full-time preschool slots, and added more full-day schools (e.g. Spiess and Wrohlich; 2008; Schober and Spiess; 2013). A longstanding special feature of the German tax code encourages differentiated division of labour (income splitting), resulting in negative employment incentives for married women (e.g. Steiner and Wrohlich; 2004).

Beyond these policies, West German society can be characterized by gender conservative views. For instance, a relative high share of the population thinks that women with children under school age or in elementary school should not work outside the home (fullor part-time) (e.g. Kleven, Landais, Posch, Steinhauer and Zweimüller; 2019). Overall, mothers in West Germany are stigmatized for pursuing careers (e.g. Collins; 2019). 
We restrict our analysis to West German society, as female labour supply decisions are systematically different in East Germany mainly due to differences in formal child care provision, differences in norms regarding maternal employment, and a greater economic necessity for women to work (e.g. Campa and Serafinelli, forthcoming; Bauernschuster and Rainer; 2012). ${ }^{8}$

As East Germans have a history of mandated employment, mothers feel less conflicted about working, although some curtail their work hours and ambitions (e.g. Collins; 2019). Although it would be interesting to assess intergenerational links in East Germany, there are several drawbacks: First, there is only very little and not very meaningful variation in the labour supply decisions of the mother-generation since almost all women were (required) to work full time in East Germany during the divided years. ${ }^{9}$ Second, in the data sets we can use for our analysis, the East German samples are very small.

Overall, the West German society is different to that of other related studies, such as the US with no comparable family policies and very different attitudes toward maternal employment. Although Swiss society exhibits similar attitudes toward maternal employment, it is different with respect to the tax, parental leave, and day care system. The study of Kleven, Landais, Posch, Steinhauer and Zweimüller (2019) refers to Denmark, a much more egalitarian society, with higher maternal employment rates and smaller child penalties.

\footnotetext{
${ }^{8}$ The result of the different systems imposed on East and West Germany during the divided years.

${ }^{9}$ Women's labour force participation in the former GDR was extremely high, one of the highest in the world (Rosenfeld et al.; 2004). Before reunification (in 1989), $91 \%$ of women participated in the labour market compared with only $51 \%$ in West Germany. Reasons for not participating in the labour force were mainly temporary (e.g. birth-related interruptions) or health-related.
} 


\section{Data and empirical approach}

\subsection{Data}

We use national representative data from the German Socio-Economic Panel (SOEP) study and the German General Social Survey (ALLBUS) to examine the intergenerational links between the labour supply choices of one generation of women and that of their mothers and mothers-in-law.

SOEP data The SOEP is an annual panel study of private households in Germany that was first implemented in 1984 in West Germany and later extended to East Germany. The panel dataset covers about 30,000 respondents from 17,000 households and has a strong focus on intergenerational aspects (Goebel et al.; 2019). In our analysis, we include all cohabiting couples, independent of their marital status, living in West-Germany where the women is aged between 25 and 55; i.e. out of education but far from retirement. ${ }^{10}$ Our main sample consists of 22,814 year observations from 3,650 different women cohabiting with a partner.

The employment status of the own mother and the mother-in-law, our main variables of interest in the analysis, are captured by indicator variables that are equal to one if the mother participated in the labour force when the respondent was aged 15 and zero otherwise. $^{11}$ This information is derived from a supplementary biography questionnaire that asks all SOEP respondents detailed questions about socio-economic and demographic characteristics of their parents and the situation during childhood. ${ }^{12}$ Unfortunately, for our main sample we do not have information on the entire working history of the women's

\footnotetext{
${ }^{10}$ Same-sex couples are dropped from the analysis.

${ }^{11}$ More precisely, the respondent is asked about the type of job the mother hold when he or she was aged 15.

${ }^{12}$ The information on mothers working status was only included starting in the year 2000. As individuals only answer the biography questionnaire once when entering the SOEP, almost all observations in our dataset are drawn from a refreshment sample of the SOEP which was selected independently from all other subsamples from the population of private households in the year 2000 .
} 
and their partners' mother or on their hours worked. ${ }^{13}$ Hence, it could be that we classify some mothers and mothers-in-law as working even though they were absent from the labour market for most of the time during the childhood of their sons and daughters. We assess this potential measurement error in the robustness section. ${ }^{14}$ Overall, 50 percent of men and 57 percent of women are classified as being brought up by a working mother. ${ }^{15}$

We focus the analysis on three main outcomes: (i) labour force participation of women; (ii) their working hours; and (iii) their gross labour income. Women are defined as participating in the labour force when they report being in regular full- or part-time employment. ${ }^{16}$ Working hours are measured as contracted weekly working hours ${ }^{17}$ and we take logs of women's gross monthly labour income. For (ii) and (iii), we also look at the outcome relative to the partner, i.e. a woman's share of working hours and gross wages within the partnership. Descriptive statistics on the main SOEP sample are presented in Table A1 in the Appendix.

ALLBUS data To examine directly if men and women who were brought up by a working mother have different social norms and attitudes, we make use of the German General Social Survey (ALLBUS). The ALLBUS is a cross-sectional dataset that is conducted biennially since 1980 (GESIS - Leibniz-Institut für Sozialwissenschaften; 2016). It covers a representative sample of the German population. In contrast to the SOEP, it has a strong focus on the attitudes and beliefs of the respondents. Similar to the SOEP,

\footnotetext{
${ }^{13}$ However, this information is available for a subsample (see robustness section).

${ }^{14}$ Moreover, there might be a simple recall error concerning the labour force status of mothers. However, when comparing the information on mothers' and mothers-in-law' working status in the SOEP to administrative statistics of female labour force participation (Statistisches Bundesamt 2017) over time, we find that our measure fits well, both in terms of levels and development of female labour force participation over time (see Figure A1 in the Appendix).

${ }^{15}$ One likely explanation for this difference is cohort effects (men are on average older than their female partner).

${ }^{16}$ The distributions of the dependent variables are depicted in Figure A2 in the appendix.

${ }^{17}$ The analysis of working hours includes women who are out of the labour force (coded as zero hours). Conditioning our sample on working women only would results in an endogenously selected sample which might yield biased estimates.
} 
we use information on women's and men's mother's working status when the respondent was aged $15 .^{18}$ This information is available starting in 2004. To investigate if men and women who are raised by working mothers develop different social norms and beliefs that are more favourable toward working women, we use the following six different statements concerning attitudes towards working mothers: (i) A working mother can just as well have a hearty and trustful relationship with her children as a non-working mother; (ii) it is even good for a child if his or her mother is employed instead of merely focusing on household work; (iii) certainly, a baby suffers if his or her mother is employed; (iv) it is more important for women to support her husband's career instead of making her own career; (v) it is better for all if the husband works and the wife stays at home taking care of household and children; and (vi) married women should turn a job down if only a limited number of jobs are available and her husband is able to make a living for the family.

The statements capture the respondents' opinion about compatibility of paid work and family related work, i.e. whether they think maternal employment has detrimental effects on children and the family, as well as about the appropriateness of specialization of male and female roles. The agreement to the various items is measured on a 4 point Likert scale ranging from 1 (completely agree) to 4 (completely disagree). The questions are only asked in the waves 2004, 2008, 2012 and 2016. ${ }^{19}$ We combine the six different items to a single index by standardizing each item and then adding up each item such

\footnotetext{
${ }^{18} \mathrm{We}$ also replicate the link between the labour force participation of women and that of their mother and mother-in-law using ALLBUS data. As in the SOEP analysis, participating in the labour force is coded as one if the women works regularly in full- or part-time. Information on women's working hours or gross labour income is not provided in the ALLBUS. It is important to note that the ALLBUS is not a household survey; rather it is targeted at individuals. Hence, when replicating the associations between the working status of women and their mothers-in-law, we use information reported by the partner. If available, we construct all control variables similar to SOEP measures. Descriptive statistics are provided in Table A2.

${ }^{19}$ In 2012 and 2016, one half of the sample was asked a slightly revised set of questions. To maintain a consistent measure across years, we drop those observations.
} 
that higher values correspond to more "traditional" social norms and views about how maternal paid work affects children and the family.

\subsection{Empirical approach}

We start out estimating simple intergenerational correlations with the following model:

$$
Y_{i j t}=\beta_{0}+\beta_{1} \text { MILworked }_{j}+\beta_{2} \text { Mworked }_{i}+X_{i j t}^{\prime} \beta_{3}+\epsilon_{i j t}
$$

where dependent variables $Y_{i j t}$ of women $i$ with partner $j$ in year $t$ are (i) labour force participation, (ii) working hours, and (iii) gross monthly labour income. For (ii) and (iii), we also look at the outcome relative to the partner $j$. MILworked $j$ is the working status of the mother-in-law, i.e. an indicator whether the partner $j$ grew up with a working mother, while Mworked $_{i}$ is the working status of the own mother when the respondents was aged 15. The model subsequently includes a rich set of control variables $X_{i j t}^{\prime}$ to control for several confounding sources of heterogeneity contained in $\epsilon_{i j t}{ }^{20}$ On the individual level, this includes the woman's and partner's age (linear and squared), years of education, religion measured in four categories corresponding to catholic, protestant, other religion and no religion, marital status, log gross labour income of the partner (linear and squared), the number of children in the household, the number of children under the age of six and the city size in three categories. Including these covariates rules out that our estimates simply reflect assortative mating in, for example, education or religion, cohort or age differences. ${ }^{21}$ In addition, we control for other parental background characteristics of the couple: in particular, mother's and father's highest educational degree in three

\footnotetext{
${ }^{20}$ In addition, we conduct several robustness checks in section 5 where we explicitly rule out potential confounding patterns.

${ }^{21}$ For example, younger cohorts of women are more likely to have a working mother-in-law and be working themselves because of the strong secular increase in female labour force participation in the 1990s and new millennium, causing a spurious correlation between mother-in-law's and wife's labour force participation. Some of these controls (e.g. fertility) might be endogenous to social norms and beliefs, we present results for different model specifications.
} 
categories corresponding to primary, secondary, and tertiary education according to the ISCED-97 classification (International Standard Classification of Education), a measure of the job prestige of the father when the respondent was aged 15 (magnitude prestige scale by Wegener (1984)) as a proxy for income and wealth of the parents, and the number of siblings. Including parental characteristics as additional control variables ensures that $\beta_{1}$ or $\beta_{2}$ capture the association with growing up with a working mother rather than having a mother who is well-educated or was living in a household with lower or higher household resources. Finally, we control for various regional characteristics at the county level in year $t$ such as the unemployment rate, employment rate, average GDP per capita, share of foreigners, the size of the county in kilometres squared and day care availability for under three year olds and for children aged between three and school entry (Statistisches Bundesamt; 2019). All models control for survey year fixed effects and are estimated with robust standard errors clustered at the couple level to take into account the fact that couples are observed more than once (within cluster correlation).

When estimating equation (1), we cannot differentiate whether the estimated coefficient $\gamma_{1}$ reflects assortative mating in other unobserved characteristics or the direct impact of the partner's social norms and beliefs on the woman's labour supply decision. ${ }^{22}$ The former would be consistent with a story where a man matches with a women who is similar to his mother in terms of unobserved social norms and beliefs regarding maternal employment and labour force attachment. The latter implies that the observed pattern is the result of a joint labour supply decision or a bargaining process where the partners' social norms are more relevant for the observed labour supply behaviour of partnered women.

To shed light on this issue, we first exploit the panel structure of the SOEP data and use additional data on all single women in the SOEP to check if the contemporaneous

\footnotetext{
${ }^{22}$ Whether a man grows up with a working mother is not a significant predictor for cohabiting with a women, i.e. is not predictive for being included in our estimation sample.
} 
labour force participation of women is correlated with the mother's working status of later partners, i.e. men they cohabit with in the future. Formally, this corresponds to estimating regressions of the following form:

$$
Y_{i f t}=\gamma_{0}+\gamma_{1} \text { MILworked }_{f}+\gamma_{2} \text { Mworked }_{i}+X_{i f t}^{\prime} \gamma_{3}+u_{i f t}
$$

where $f$ is the partner that single women $i$ is cohabiting or married with in the future, i.e. in $t=t+n, n \in\{1, \ldots, N\}$. If our main estimates reflect associative mating in unobserved characteristics that are correlated with the labour supply decision of women, we would expect to find a similar correlations already before women form a partnership.

In addition, the panel setting offers the chance to include individual fixed effects on the women level which formally reads:

$$
Y_{i j t}=\delta_{0}+\delta_{1} M I \text { Lworked }_{j}+X_{i j t}^{\prime} \delta_{2}+\mu_{i}+\xi_{i j t}
$$

In equation (3), the identifying variation comes from women who we observe changing their partner, i.e. from variation in the labour force status of the mother MILworked ${ }_{j}$ of the old and new partner. ${ }^{23}$ Including individual fixed effects $\mu_{i}$ controls for all potential time-constant confounding factors, e.g. time-constant preferences for a particular type of men or time-constant preferences for a particular division of paid work. In addition, we control for the same set of time-varying characteristics as in equation (3), e.g. time-varying characteristics of the current partner.

\footnotetext{
${ }^{23}$ Note that, in this regression, we do not drop women with missing information on time constant covariates because this would reduce the number of women observed switching their partner substantially. Overall, we observe 212 women changing their partner for on average four years after the change in partners.
} 


\section{Results}

\subsection{Main results}

We start by estimating simple intergenerational correlations between female labour force participation of different generations using equation (1). The results in Table 1 show that having a partner who grew up with a working mother is associated with a significant increase in the probability that a women does paid work by about 7 percentage points. ${ }^{24}$ Including the rich set of additional control variables described in the previous section leaves the coefficient unchanged, suggesting that the results are not driven by, for example, systematic differences in religion, education, and cohort or age differences. ${ }^{25}$ In particular, we also control for the working status of the women's own mother during youth. In line with the findings by Fernández et al. (2004), this does not change the estimated coefficient. The point estimate on the own mother's labour force participation is small and not statistically significant. Whether the partner grew up with a working mother is more predictive than the working status of the own mother for female labour supply decisions in couples.

Furthermore, the results in Table 2 indicate that having a partner who grew up with a working mother is associated with an increase in women's weekly working hours ${ }^{26}$ and gross labour income. The coefficients amount to an increase in contracted working hours of about 1-2 hours per week and an increase in gross weekly labour earnings of about 40 percent. Interestingly, for gross labour income, the working status of the own mother as an adolescent is an equally strong predictor as the mother-in-law's working status. However, this does not hold when examining labour income shares. Reassuringly, the association

\footnotetext{
${ }^{24}$ Using ALLBUS data, the findings in Table A5 are very similar to Table 1, which is not surprising given that both surveys are representative of the (West) German population and cover similar survey years.

${ }^{25}$ The coefficients for all the control variables in the SOEP data are shown Table A4 in the Appendix.

${ }^{26}$ Please note that the analysis includes women who are out of the labour force to avoid any selection bias.
} 
with the mother-in-law's working status is also large and significant when looking at the working hours and earnings relative to the partner, i.e. the share of of working hours provided by the women and the share of income. Having a working mother-in-law is associated with an increase in the share of gross labour earnings provided by the women of about 3 percent (about 10 percent relative to the mean) and an increase in the women's share of hours worked by about 3 percent (about 9 percent relative to the mean).

To learn more about whether the mother-in-law matters most for moving women from no employment to part-time, from part-time to full-time, or from full-time to long hours, we also conduct the analysis using full-time, part-time and marginal employment as an outcome. This yields the following results: The working status of the motherin-law is a slightly stronger predictor for working part-time (0.045) than working fulltime (0.030). Interestingly being marginally employed is negatively (-0.012), but not significantly, associated with having a partner who grew up with a working mother. This result is confirmed when splitting up working hours categories and running a regression on each dummy (Figure A3).

Heterogeneity analysis in Table A6 shows that the correlation is significantly larger for married women and is increasing with marriage duration. ${ }^{27}$ This could be related to the quality of the relationship and the intensity of the partners' effects on one another. In addition, the correlation seems to be stronger for women who have less education than their partner and women whose father had a job with lower prestige than the father of their partner; i.e. couples where the women potentially has less bargaining power than her partner. ${ }^{28}$ Examining heterogeneities by the size of the municipality, religion of the women and number of children in Table A7 reveals the following pattern: The intergenerational link is strongest in more rural municipalities but not significant and

\footnotetext{
${ }^{27}$ This information is not available for all observations, which reduces the number of observations, thus increasing standard errors.

${ }^{28}$ Father's job prestige as a measure of family status or wealth and relative education are commonly used indicators of bargaining power when testing household bargaining models in the economic and sociological literature.
} 
much smaller in urban areas with more than 100,000 inhabitants. As rural regions tend to be more conservative in the sense that less women are working it could be that in such an environment in particular the men's attitudes play a major part in explaining their partners employment outcomes, while in urban areas women on average are more work oriented anyway. Interestingly for women with no confession it does not seem to play a role whether they have a partner who grew up with a working mother or if they themselves were brought up by a working mother, while the latter seems to be especially relevant for women with other non-christian religion (mainly Muslims). Religiousity maybe a factor because it can be assumed to be related to perceptions of appropriate gender roles, and such roles are closely associated with the gender division of labour (Iversen and Rosenbluth; 2006). The result are very similar for couples with no and up to two children in the household. However, when looking at women with three or more children the working status of the own mother becomes highly predictive of women's own labour market outcomes. These are women who on average either do not work at all or with very few hours.

Further, we show heterogeneous effects by age. Differentiating by the age of the women in Figure A4 shows that while women of working and non-working mothers-in-law exhibit very similar participation rates before the age of 20 , the difference between these two groups grows larger and statistically significant once they reach the child-bearing age. The gap is largest and statistically significant in the 30 s and 40 s, i.e. when most women have young children. It decreases a bit starting at age 40, however remains statistically significant until age 60. This is confirmed when plotting the coefficients for our outcomes of interest using different age group subsamples (Figure A5): effects are strongest for women in their 30s and 40s. 


\subsection{Explaining the intergenerational labour supply links}

There are several potential mechanisms that could explain why women with partners who grew up with a working mother have, on average, a higher labour force participation, work longer hours, and have higher labour income. In the following, we examine three potential mechanisms in more detail: First, we analyse whether men who grew up with a working mother develop different social norms and attitudes towards working women than other men. Second, we examine if partners who grew up with a working mother spent more time on unpaid work such as housework and childrearing, thus allowing the women to spend more time on paid work. Third, we carefully assess whether the intergenerational correlation reflects assortative mating or can be interpreted as an outcome of a joint labour supply decision or bargaining process where the partner's preferences determine the labour supply decision of women in couple households.

Social norms and attitudes Concerning stated social norms and beliefs about how maternal employment affects children and the family, Table 3 shows that the working status of the own mother during childhood is a strong predictor for contemporaneous attitudes regarding the appropriate role of women, especially for men (Panel A): Men brought up by a working mother have much less "traditional" beliefs and attitudes towards working women than other men. For men, the difference amounts to about 12 percent of a standard deviation. It is highly statistically significant and robust to the inclusion of various control variables. This is line with simple descriptive evidence in Figure A6 for all single items of the index. ${ }^{29}$ For women, this link is slightly smaller (about 8 percent of a standard deviation) and in our preferred specification statistically significant at the 5 percent level. ${ }^{30}$ Looking at single men and women reveals that mother's working status is

\footnotetext{
${ }^{29}$ Estimation results for single items are available upon request.

${ }^{30}$ Similar findings were already reported by Powell and Steelman (1982), showing that the association between maternal status characteristics and gender role attitudes of adult men is stronger than for adult women.
} 
an equally strong predictor for social norms and beliefs in adulthood for men and women. However, the coefficients are not as precisely estimated due to the smaller sample sizes.

Non-paid work We find no evidence that men raised by working mothers spent more time on housework or childrearing. The results in Table 4 suggest that neither the average time (in hours per day) women and men spent on housework during a typical workday, nor the time spent on childrearing differ significantly by whether or not the partner grew up with a working mother. Thus, our main estimates in Tables 1 and 2 cannot be explained by the fact that men who grew up with a working mother have different household skills or preferences to cooperate in the household, which might lead to a larger engagement in housework or childrearing.

Fertility Preferences and Decisions The link between the employment status of the mother-in-law and women's employment might also run through fertility preferences and decisions (see e.g. Kleven, Landais and Søgaard; 2019). We show with our data that fertility outcomes are strongly correlated across generations. Thereby, the number of siblings of the women and of her partner are equally strong predictors for the number of children a couple has. Conducting our baseline analysis (specification (1)) using the number of children as an outcome yields negative coefficients, but they are not significant. $^{31}$ Interestingly and in contrast to our main results, the working status of the own mother of the women is a stronger (negative) predictor for the number of children a couple has, than the working status of the mother-in-law. Overall, the insignificant effect hints that the transmission of labour market outcomes of the woman does not occur through the transmission of fertility preferences, but rather through gender norms of the couple, respectively the partner (see e.g. Kleven, Landais and Søgaard; 2019, for this finding in the context of child penalties of maternal employment).

\footnotetext{
${ }^{31}$ These results are available by the authors upon request.
} 
Assortative mating So far, the analysis suggests that the intergenerational link between the labour supply decision of women and their mother-in-law is driven by the preferences of the partner, i.e. it is the outcome of a joint labour supply decision or bargaining process where the partner's preferences dominate. However, it could also be that our estimates reflect assortative mating in other unobserved characteristics that we cannot control for (e.g. Morrill and Morrill; 2013). One example could be that women, who themselves have a higher labour market attachment or career aspirations, are more likely to select a partner who is supportive of that and in favour of the dual earner household model. To shed light on this, we first use additional data on single women and examine whether women who later have a partner who grew up with a working mother already exhibit different labour market outcomes before matching with their future partner. ${ }^{32}$ Second, we exploit the fact that we observe the same women with different partners over time, i.e. we net-out any remaining time-invariant unobserved heterogeneity by including individual fixed effects. Although it would have been interesting as well to observe the change in norms over time to answer the question if assortive mating plays a role, we are not able to do this given the structure of the ALLBUS data that we use to capture norms and attitudes. This is a cross-sectional dataset.

The estimates using single women in Panel A of Table 5 show that there is no significant correlation between the contemporaneous labour market outcomes of women and the indicator for having later a mother-in-law who worked, i.e. whether or not the women will have a partner who grew up with a working mother in the future. Thus, before matching with a partner, there are no differences between the labour market outcomes of women who later have a partner who grew up with a working mother and women who later have a partner who grew up with a non-working mother. This suggest that there is no assortative mating on realized labour market outcomes and that the intergenerational

\footnotetext{
${ }^{32}$ As expected the the sample of single women has higher labour force participation than the sample of partnered women. Unfortunately, we can not conduct the same analysis using social norms as an outcome because the ALLBUS data is a cross-sectional data set.
} 
labour supply links are not driven by the fact that women who themselves have a higher labour market attachment are more likely to select a partner who supports her. ${ }^{33}$ However, standard errors are relatively large due to the smaller sample size. Also note that, due to the sampling structure of the SOEP, which is based on a household concept, we cannot rule out that the future cohabiting or married partner of a women is her partner already, but not living in the same household. However, this would bias the coefficient of interest upwards, thus provide us with a lower bound. Including individual fixed effects in Panel B of Table 5 shows that the correlations between the working status of the partner's mother during adolescence and own labour market outcomes are a bit larger than in our main specification and remain statistically significant when including time-varying covariates. Under the assumption that patterns of partnership formation and preferences for a particular type of men are constant within individuals across time, this result also suggests that our findings are not an outcome of assortative mating, but result from gender-specific processes in the formation of preferences during childhood and adolescence, along with subsequent household behaviour in later adulthood. This interpretation is supported by the heterogeneity analysis discussed above (Table A6), which indicates that the intergenerational links are stronger in couples where the woman has potential lower bargaining power and for women where we would expect social norms to play a more important role.

It is also in line with other research showing that in many decisions that couples take jointly, the preferences of the male decision maker determine the outcome. Examples include the choice where to live (e.g. Løken et al.; 2013), the level and type of public good provision (e.g. Andreoni et al.; 2003) or retirement decisions (e.g. Hiedemann; 1998; Lundberg et al.; 2003). This is also confirmed in more aggregated state-level analysis on women's relative to male's labour market outcomes, e.g. Charles et al. (2009) show that

\footnotetext{
${ }^{33}$ Another reason for this result might be that the women is highly likely to be employed when she was a single, and considers only later, when she is partnered with children, to leave the labour force. Therefore we refer to Panel B as well.
} 
after controlling for men's views regarding gender roles, women's attitudes are no longer a significant predictor for their labour market outcomes.

\section{Robustness}

In the following, we rule out several potential confounding patterns and conduct several robustness and sensitivity tests to our main estimates.

\section{$5.1 \quad$ Rule out other confounding patterns}

Early socialization vs. current involvement of mother-in-law First, we test whether our results could be driven by the current involvement of the mother-in-law rather than early socialization of her son. The former could be the case if mothers-inlaw actively engage in women's decision if and how to participate in the labour market. For example, it could be that a mother-in-law with a higher attachment to the labour market more actively supports the compatibility of paid work and family duties of her daughter-in-law, e.g. by providing childcare. To assess this hypothesis, we estimate our main specifications in the sample of women where the mother-in-law has already died and in a sample of women who do not live close to their mother-in-law. Results in Panel A of Table 6 suggest that our estimates remain very similar in magnitude however loose precision due to the smaller sample sizes. This indicates that our main findings do not reflect spurious correlation due to a current local involvement of the mother-in-law and can be interpreted in the direction of early socialization.

Local culture, peer effects or other regional labour market conditions Second, we assess whether our estimates reflect variation in local culture, local peer effects (Mota et al.; 2016; Olivetti et al., forthcoming) or other regional labour market conditions, which 
are not captured by the regional indicators that we control for in our main specification. ${ }^{34}$ These factors can cause a spurious correlation between women's labour market outcomes and mother-in-law's labour force participation that is driven by regional characteristics. To test this, we include county averages of maternal labour force participation of women's peers as an additional control. ${ }^{35}$ Thus, we test if our main coefficients reflect peer effects rather than the association with mothers-in-law labour force status. In addition, we estimate a specification with regional fixed effects (NUTS-2 level) to capture further local effects. The estimated coefficients in Panel B of Table 6 remain very similar to our baseline estimates. The coefficients on the average labour force participation of the women's peers in the same labour market are large, but imprecisely estimated.

Finally, we randomly rematch women with men living in the same NUTS 2 region using 5,000 independent draws and test whether the correlation in these synthetic couples is similar to the correlation observed within real couples. The distribution of these 5,000 placebo estimates are depicted in Figure A7, when the outcome is (a) labour force participation; (b) weekly working hours; and (c) log gross monthly earnings. The vertical lines indicate the baseline estimates from Table 1 and Table 2. Reassuringly, for each outcome, the placebo coefficients are centred around zero and are always smaller than the true coefficient. They tend to shift even closer towards zero when including the rich set of covariates. This suggests that our main estimates are not driven by regional unobserved heterogeneity.

\footnotetext{
${ }^{34}$ Note that Column (6) in Table 1 and Table 2 already controls for a set of regional characteristics, including city size, unemployment rate, employment rate, average GDP per capita, share of foreigners, provision of publicly funded day care, and the size of the county that the couples is living in.

${ }^{35}$ The averages are calculated using all individuals in the SOEP with non-missing information on mothers' labour force participation to obtain the best available measure, i.e. mothers' and mothers-inlaw's participation. On average we observe 70 individuals per year (1210 averaged over all years) in one county.
} 


\subsection{Other robustness checks}

Systematic recall error First, we check if our results could be driven by a systematic recall error in mothers working status. For example, due to the retrospective reporting, it could be that the partner is more likely to state that his mother was working if he observes that his female partner is participating in the labour force, even though the mother may have started working later on or not at all. ${ }^{36}$ This would result in a positive coefficient even though no (causal) relationship exists. ${ }^{37}$

To overcome this concern, we run the same analyses using an additional constructed smaller SOEP dataset in which we exploit the household panel structure and the followup concept of the SOEP. This allows us to directly link individuals to their parents and observe them during their childhood, adolescence, and after they grow up and continue to live in different households. In this follow up subsample, we include all men (i.e. partners) from original SOEP households whose parents we observe at least once during their childhood (age 7 - age 18). We restrict the sample of women with a partner from original SOEP households to the same survey years as our main estimation sample (2000 - 2017). Overall, this gives us information on 3,611 year observations from 485 women who have a partner from an original SOEP household. We define the mother-in-law as working if we observe her to be working most of the time in regular full or part-time employment when their son was aged between 7 and 18 and non-working otherwise. The set of controls is constructed accordingly (see Table A3 for descriptive statistics). ${ }^{38}$ The advantage of this SOEP subsample is that there is no reporting error in our data since we observe the mother-in-law's labour force status in the original SOEP households directly.

\footnotetext{
${ }^{36}$ Note that this concern is mitigated by the fact that the respondent is asked about the type of job the mother hold when he or she was aged 15 not the working status of the mother per se.

${ }^{37}$ Since recall errors tend to increase as respondents are asked to think further back in time (Ebbinghaus; 1894), we additionally conduct the analysis for individuals who were still rather young when they answered the biography questionnaire. The results are very similar to our main estimates.

${ }^{38}$ Note that with this subsample we can use an even more precise measure for household income: We take the average value of household income over the observed period to reduce measurement error induced by transitory income fluctuations.
} 
In addition, we can observe the full working history of the mother-in-law. Point estimates in Panel $\mathrm{C}$ of Table 6 are larger in magnitude than our main estimates in Table 1 and Table 2 and highly statistically significant for all outcomes. ${ }^{39}$ Having a partner who grew up with a working mother is associated with an increase in the probability to participate in the labour force by about 11 percentage points, an increase in weekly hours worked by about 3 hours (17 percent of mean) and earnings by 80 percent (18 percent relative to mean).

\section{Different sample restrictions and functional form assumptions Moreover, we} conduct different sensitivity analyses regarding sample restrictions and functional form assumptions. For example, we estimate a more flexible specification using age (or birth year/cohort) dummies as controls that might be better able to exclude that our estimates are driven by cohort effects. This allows to interpret the results more directly as making comparisons between women who do and don’t have a mother-in-law who worked within the same survey year and cohort. In addition, we specify an alternative definition for our samples to account for potential overweighting of more frequently observed couples due to the unbalanced structure of our panel; i.e. we weight each couple by the inverse frequency the couple is encountered in the data. Next, we also restrict the age of the partner to be between 25 and 50 to mitigate noise in the working status of the partner related to retirement or education decisions. As a final robustness check, we drop couples where at least one of the partner's place of residence before unification was in East Germany. Individuals who grew up under the former GDR regime developed very different

\footnotetext{
${ }^{39}$ One potential reason for the larger estimates is that we take modes of the observed labour force participation of the mother, i.e. an indicator equal to one if we observe the mother more often to be working than non-working. Thus, this group of working mothers is likely to have a higher labour force attachment than the group of working mothers in our main estimation sample. The results are robust to various ways to construct the working status of mothers, i.e. using different observation windows, or when using hours worked as a dependent variable. Notably, the coefficients become even larger when using measures of mother's labour supply during childhood. Another potential explanation could be that the couples in the constructed follow-up sample are younger and have smaller children than couples in our main sample (see Table A3 for details).
} 
social norms and beliefs regarding maternal employment (e.g. Campa and Serafinelli, forthcoming; Bauernschuster and Rainer; 2012). Since almost all individuals who lived in East Germany before reunification report that they grew up with a working mother, it is impossible to differentiate between the effect of growing up in East Germany and the impact of growing up with a working mother. Results reported in Table A8 in the Appendix show that our estimated are not sensitive to these additional robustness checks and remain statistically significant. We also asses the sensitivity of our results to using linear probability models and ordered probit models (for categorical variables). ${ }^{40}$

\section{Conclusion}

Overall, the findings of this study shed light on the persistence and importance of social norms for economic outcomes. In particular, this study contributes to the literature on intergenerational links in explaining the rise in female labour force participation. Based on much larger and richer panel data sets then previous studies, we show that the female labour market outcomes of partnered women between 25 and 55 years of age, at the extensive and the intensive margin, are influenced by the labour force participation of their own mother and their mother-in-law. However, the influence of the mother-in-law's labour market participation is economically more significant: Having a partner who grew up with a working mother increases the probability that a woman does paid work by about 7 percentage points, it increases her contracted working hours by about 1-2 hours per week, and we can observe an increase in her gross weekly labour earnings of about 40 percent. What we capture when we measure the mothers' labour force participation is the labour market participation during adolescence - a phase when gender stereotypes of children are formed in particular.

\footnotetext{
${ }^{40}$ These additional robustness checks can be obtained from the authors upon request.
} 
In comparison to existing studies, our data sets allow for a particularly detailed focus on various explanations for the intergenerational links in labour market outcomes. First, our study suggests that these links cannot be explained by assortative mating; rather, it can be interpreted as evidence that the partner's preferences play a decisive role for labour supply decisions of women. Second, we show that men brought up by a working mother have much less "traditional" beliefs and attitudes toward working women than other men. However, men who grew up with a working mother have no different household skills or preferences to cooperate in the household, which could have been another explanation. However, this also means that men support their partner's labour force participation but do nothing with respect to housework to facilitate the employment of their partner. Given that some of the more recent gender and family literature comes to the conclusion that further progress in terms of gender equality in the labour market will depend on men's contributions to housework (e.g. Williams; 2010), our findings show that this channel might not be so effective - at least in the West German case.

Further analyses for heterogeneous groups show that the correlation is mainly driven by couples living in more rural areas, Christian women and women with less than three children. Furthermore, it is larger for married women, increases with marriage duration, and seems to be stronger for women who have less education than their partner. Given a decreasing share of couples who get married (Statistisches Bundesamt; 2018b), the overall correlation might decrease slightly for future generations, all else equal. The same might be the case if we consider the rising share of women who are better educated than their partner (Statistisches Bundesamt; 2018a) or the increasing share of non-religious individuals.

Overall, our paper contributes to the literature that examines how attitudes and resulting social norms influence the evolution of the economy, such as female labour force participation. A few studies investigate, based on detailed data, the intergenerational link of female labour force participation for countries outside the EU. To our knowledge, we 
are the first showing this based on West German data and, thus, for a society with gender conservative views and a particularly high child penalty for female employees. Parenthood and care are mostly considered as a private responsibility and, although there is a change in some fields of family policies, the share of part-time working women is still particularly high.

Thus, our results indicate that the intergenerational links also apply to part-time working generations. Our data does not allow us to investigate how the intergenerational link would change if we divide our sample into part- and full-time working mothers-inlaw. Moreover, further research with even richer data sets might help to capture the exposure to different models of reconciling work and family life during adolescence in more detail. This might shed even more light on which combination of work and family life has the strongest influence on the type of children's and their partner's later labour market outcomes once they are adults. However, to our knowledge no data sets that would allow for an analysis based on a large enough sample exist. Apart from this, our analysis shows that all family policy related measures that support maternal labour force participation, such as father quotas in parental leave regulations, affordable and available formal day care, all-day schooling, family friendly work-place policies, and many other measures, might not only have effects on the employment and gender norms of the current workforce of women (e.g. Zoch and Schober; 2018; Unterhofer and Wrohlich; 2017) but also on the future workforce, via the children of these mothers, particularly via their sons. Thus, evaluating such policy measures must also take the effects on the next generation into account - leading to much larger societal benefits when tax returns and social security benefits of the next generation in the labour market are added as well. 
Table 1: Female labour force participation

\begin{tabular}{lccccccc}
\hline & $(1)$ & $(2)$ & $(3)$ & $(4)$ & $(5)$ & $(6)$ & $(7)$ \\
\cline { 2 - 7 } Mean of dep. variable & 0.626 & 0.626 & 0.626 & 0.626 & 0.626 & 0.626 & 0.626 \\
\hline Mother-in-law worked & $0.072^{* * *}$ & $0.063^{* * *}$ & $0.072^{* * *}$ & $0.072^{* * *}$ & $0.071^{* * *}$ & $0.076^{* * *}$ & $0.073^{* * *}$ \\
& $(0.022)$ & $(0.022)$ & $(0.022)$ & $(0.023)$ & $(0.022)$ & $(0.023)$ & $(0.022)$ \\
Own mother worked & & & & & & 0.027 & 0.025 \\
& & & & & & $(0.023)$ & $(0.023)$ \\
Controls & & & & & & & \\
Partner characteristics & $\checkmark$ & & $\checkmark$ & $\checkmark$ & $\checkmark$ & $\checkmark$ & $\checkmark$ \\
Own characteristics & & $\checkmark$ & $\checkmark$ & $\checkmark$ & $\checkmark$ & $\checkmark$ & $\checkmark$ \\
Household characteristics & & & & $\checkmark$ & & $\checkmark$ & $\checkmark$ \\
$\begin{array}{l}\text { Partner's parents characteristics } \\
\text { Own parents characteristics }\end{array}$ & & & & & $\checkmark$ & $\checkmark$ & $\checkmark$ \\
Regional characteristics & & & & & & & $\checkmark$ \\
Observations & 22814 & 22814 & 22814 & 22814 & 22814 & 22814 & 22814 \\
$R$-squared & 0.050 & 0.038 & 0.062 & 0.120 & 0.053 & 0.125 & 0.129 \\
\hline
\end{tabular}

Note: Probit estimates. Marginal effects calculated at the mean of the independent variables. See

Table A1 for list of control variables. Regressions are weighted using provided survey weights. * $p<0.1,{ }^{* *} p<0.05,{ }^{* * *} p<0.01$.

Source: SOEP v.33, Statistisches Bundesamt (2019), own calculation.

Table 2: Working hours and labour income

\begin{tabular}{|c|c|c|c|c|c|c|c|c|}
\hline \multirow[b]{4}{*}{ Mean of dep. variable } & \multicolumn{4}{|c|}{ Weekly working hours } & \multicolumn{4}{|c|}{ Log gross monthly labour income } \\
\hline & \multicolumn{2}{|c|}{ Total } & \multicolumn{2}{|c|}{ Relative to partner } & \multicolumn{2}{|c|}{ Total } & \multicolumn{2}{|c|}{ Relative to partner } \\
\hline & (1) & $(2)$ & (3) & $(4)$ & (5) & $(6)$ & $(7)$ & $(8)$ \\
\hline & 18.946 & 18.946 & 0.329 & 0.329 & 5.192 & 5.192 & 0.291 & 0.291 \\
\hline Mother-in-law worked & $\begin{array}{l}1.874^{* *} \\
(0.740)\end{array}$ & $\begin{array}{l}1.491^{* *} \\
(0.685)\end{array}$ & $\begin{array}{l}0.028^{* * *} \\
(0.010)\end{array}$ & $\begin{array}{l}0.028^{* * *} \\
(0.009)\end{array}$ & $\begin{array}{l}0.450^{* * *} \\
(0.148)\end{array}$ & $\begin{array}{l}0.390^{* * *} \\
(0.140)\end{array}$ & $\begin{array}{c}{ }^{*} 0.028^{* * *} \\
(0.009)\end{array}$ & $\begin{array}{l}0.028^{* * *} \\
(0.008)\end{array}$ \\
\hline Own mother worked & & $\begin{array}{c}0.579 \\
(0.698)\end{array}$ & & $\begin{array}{c}0.002 \\
(0.009)\end{array}$ & & $\begin{array}{c}0.320^{* *} \\
(0.139)\end{array}$ & & $\begin{array}{l}-0.001 \\
(0.008)\end{array}$ \\
\hline Full set of controls & & $\checkmark$ & & $\checkmark$ & & $\checkmark$ & & $\checkmark$ \\
\hline Observations & 19913 & 19913 & 15649 & 15649 & 22814 & 22814 & 22072 & 22072 \\
\hline$R$-squared & 0.111 & 0.262 & 0.509 & 0.592 & 0.077 & 0.188 & 0.106 & 0.192 \\
\hline
\end{tabular}

Note: OLS estimates. See Table A1 for list of control variables. Columns (7) and (8) is estimated without controlling for partner's labour income. The mean of log monthly gross income corresponds to about 1348 euros. Regressions are weighted using provided survey weights. ${ }^{*} p<0.1,{ }^{* *} p<0.05,{ }^{* * *} p<0.01$.

Source: SOEP v.33, Statistisches Bundesamt (2019), own calculation. 
Table 3: Agreement to social norms and beliefs - index

\begin{tabular}{|c|c|c|c|c|}
\hline \multirow[t]{2}{*}{ Panel A: } & \multicolumn{2}{|c|}{ partnered men } & \multicolumn{2}{|c|}{ single men } \\
\hline & (1) & (2) & (3) & (4) \\
\hline Own mother worked & $\begin{array}{l}-0.118^{* * *} \\
(0.037)\end{array}$ & $\begin{array}{l}-0.116^{* * *} \\
(0.037)\end{array}$ & $\begin{array}{l}*-0.118^{* * *} \\
(0.046)\end{array}$ & $\begin{array}{c}*-0.088^{* *} \\
(0.046)\end{array}$ \\
\hline Full set of controls & & $\checkmark$ & & $\checkmark$ \\
\hline $\begin{array}{l}\text { Observations } \\
R \text {-squared }\end{array}$ & $\begin{array}{l}1115 \\
0.167\end{array}$ & $\begin{array}{l}1115 \\
0.269\end{array}$ & $\begin{array}{c}777 \\
0.170 \\
\end{array}$ & $\begin{array}{c}777 \\
0.205\end{array}$ \\
\hline \multirow[t]{2}{*}{ Panel B: } & \multicolumn{2}{|c|}{ partnered women } & \multicolumn{2}{|c|}{ single women } \\
\hline & (1) & $(2)$ & (3) & (4) \\
\hline Own mother worked & $\begin{array}{l}-0.086^{* *} \\
(0.034)\end{array}$ & $\begin{array}{l}-0.082^{* *} \\
(0.035)\end{array}$ & $\begin{array}{l}-0.123^{*} \\
(0.069)\end{array}$ & $\begin{array}{l}-0.128^{*} \\
(0.070)\end{array}$ \\
\hline Full set of controls & & $\checkmark$ & & $\sqrt{ }$ \\
\hline $\begin{array}{l}\text { Observations } \\
R \text {-squared }\end{array}$ & $\begin{array}{l}1492 \\
0.177\end{array}$ & $\begin{array}{c}1492 \\
0.180\end{array}$ & $\begin{array}{c}357 \\
0.102\end{array}$ & $\begin{array}{c}357 \\
0.162\end{array}$ \\
\hline
\end{tabular}

Note: The dependent variable is a standardized index, derived by standardizing the agreement to social norms and beliefs shown in section 2 (measured on 4-point scale) and then adding up each item. Higher values correspond to more traditional social norms and beliefs about how maternal employment affects children and the family. See Table A2 for list of control variables. ${ }^{*} p<0.1,{ }^{* *} p<0.05,{ }^{* * *} p<0.01$.

Source: ALLBUS 2004, 2008, 2012 and 2016, own calculation.

Table 4: Time spent on housework and child care

\begin{tabular}{|c|c|c|c|c|}
\hline \multirow[b]{3}{*}{ Mean of dep. variable } & \multicolumn{2}{|c|}{ Time spent on housework } & \multicolumn{2}{|c|}{ Time spent on child care } \\
\hline & $\begin{array}{c}\text { Partner } \\
\text { (1) }\end{array}$ & $\begin{array}{c}\text { Women } \\
(2)\end{array}$ & $\begin{array}{c}\text { Partner } \\
(3)\end{array}$ & $\begin{array}{c}\text { Women } \\
(4)\end{array}$ \\
\hline & 0.702 & 2.549 & 0.836 & 3.097 \\
\hline Mother-in-law worked & $\begin{array}{c}0.013 \\
(0.020)\end{array}$ & $\begin{array}{l}-0.040 \\
(0.045)\end{array}$ & $\begin{array}{l}-0.010 \\
(0.049)\end{array}$ & $\begin{array}{c}0.118 \\
(0.105)\end{array}$ \\
\hline Own mother worked & $\begin{array}{l}-0.005 \\
(0.020)\end{array}$ & $\begin{array}{c}0.080 \\
(0.045)\end{array}$ & $\begin{array}{l}0.119^{* *} \\
(0.048)\end{array}$ & $\begin{array}{c}0.080 \\
(0.106)\end{array}$ \\
\hline Full set of controls & $\checkmark$ & $\checkmark$ & $\checkmark$ & $\checkmark$ \\
\hline Observations & 22876 & 22861 & 22873 & 22873 \\
\hline$R$-squared & 0.157 & 0.244 & 0.226 & 0.458 \\
\hline
\end{tabular}

Note: Time spent on housework or child care measured as hours per typical workday. See Table A1 for list of control variables. Regressions are weighted using provided survey weights. ${ }^{*} p<0.1,{ }^{* *} p<0.05$, ${ }^{* * *} p<0.01$.

Source: SOEP v.33, Statistisches Bundesamt (2019), own calculation. 
Table 5: Female labour market outcomes - assortative mating

\begin{tabular}{|c|c|c|c|c|c|c|}
\hline \multirow[t]{3}{*}{ Panel A: } & \multicolumn{6}{|c|}{ Future partner correlates - single women } \\
\hline & \multicolumn{2}{|c|}{$\begin{array}{l}\text { Labour force } \\
\text { participation }\end{array}$} & \multicolumn{2}{|c|}{$\begin{array}{l}\text { Weekly } \\
\text { working hours }\end{array}$} & \multicolumn{2}{|c|}{$\begin{array}{l}\text { Log gross monthly } \\
\text { labour income }\end{array}$} \\
\hline & (1) & $(2)$ & (3) & $(4)$ & (5) & (6) \\
\hline Mean of dep. variable & 0.702 & 0.702 & 24.939 & 24.939 & 5.602 & 5.602 \\
\hline Future mother-in-law worked & $\begin{array}{l}-0.007 \\
(0.041)\end{array}$ & $\begin{array}{c}0.008 \\
(0.039)\end{array}$ & $\begin{array}{c}-0.222 \\
(1.670)\end{array}$ & $\begin{array}{c}-0.333 \\
(1.539)\end{array}$ & $\begin{array}{l}-0.007 \\
(0.295)\end{array}$ & $\begin{array}{c}0.059 \\
(0.272)\end{array}$ \\
\hline Own mother worked & & $\begin{array}{l}-0.025 \\
(0.042)\end{array}$ & & $\begin{array}{l}-0.716 \\
(0.292)\end{array}$ & & $\begin{array}{l}-0.180 \\
(1.705)\end{array}$ \\
\hline Full set of controls & & $\checkmark$ & & $\checkmark$ & & $\checkmark$ \\
\hline Observations & 1718 & 1718 & 1505 & 1505 & 1718 & 1718 \\
\hline$R$-squared & 0.006 & 0.140 & 0.008 & 0.165 & 0.002 & 0.160 \\
\hline \multirow[t]{3}{*}{ Panel B: } & \multicolumn{6}{|c|}{ Fixed effects estimates } \\
\hline & \multicolumn{2}{|c|}{$\begin{array}{l}\text { Labour force } \\
\text { participation }\end{array}$} & \multicolumn{2}{|c|}{$\begin{array}{c}\text { Weekly } \\
\text { working hours }\end{array}$} & \multicolumn{2}{|c|}{$\begin{array}{l}\text { Log gross monthly } \\
\text { labour income }\end{array}$} \\
\hline & $(1)$ & $(2)$ & $(3)$ & $(4)$ & $(5)$ & (6) \\
\hline Mean of dep. variable & 0.620 & 0.620 & 18.855 & 18.855 & 5.165 & 5.165 \\
\hline Mother-in-law worked & $\begin{array}{l}0.104^{*} \\
(0.055)\end{array}$ & $\begin{array}{l}0.145^{* *} \\
(0.059)\end{array}$ & $\begin{array}{l}3.602^{* *} \\
(1.565)\end{array}$ & $\begin{array}{l}5.217^{* * *} \\
(1.607)\end{array}$ & $\begin{array}{c}0.598 \\
(0.367)\end{array}$ & $\begin{array}{l}0.990^{* *} \\
(0.392)\end{array}$ \\
\hline Full set of controls & & $\checkmark$ & & $\checkmark$ & & $\checkmark$ \\
\hline Observations & 34774 & 34774 & 30513 & 30513 & 34774 & 34774 \\
\hline$R$-squared & 0.008 & 0.066 & 0.015 & 0.105 & 0.010 & 0.078 \\
\hline
\end{tabular}

Note: Columns (1) and (2) report marginal effects evaluated at the mean of the independent variables (probit estimation). See Table A1 for list of control variables. Regressions are weighted using provided survey weights. ${ }^{*} p<0.1,{ }^{* *} p<0.05,{ }^{* * *} p<0.01$.

Source: SOEP v.33, Statistisches Bundesamt (2019), own calculation. 
Table 6: Female labour market outcomes - rule out alternative explanations

\begin{tabular}{|c|c|c|c|c|c|c|}
\hline \multirow{3}{*}{ Panel A } & \multicolumn{2}{|c|}{$\begin{array}{l}\text { Labour force } \\
\text { participation }\end{array}$} & \multicolumn{2}{|c|}{$\begin{array}{c}\text { Weekly } \\
\text { working hours }\end{array}$} & \multicolumn{2}{|c|}{$\begin{array}{l}\text { Log gross monthly } \\
\text { labour income }\end{array}$} \\
\hline & \multicolumn{6}{|c|}{ Early socialization vs. current involment } \\
\hline & $\begin{array}{l}\text { Mother- } \\
\text { lives far } \\
\text { away } \\
(1)\end{array}$ & $\begin{array}{c}\text {-in-law } \\
\text { died } \\
\text { already } \\
(2)\end{array}$ & $\begin{array}{l}\text { Mother- } \\
\text { lives far } \\
\text { away } \\
(3)\end{array}$ & $\begin{array}{l}\text { in-law } \\
\text { died } \\
\text { already } \\
(4)\end{array}$ & $\begin{array}{l}\text { Mother-i } \\
\text { lives far } \\
\text { away } \\
(5)\end{array}$ & $\begin{array}{l}\text { in-law } \\
\text { died } \\
\text { already } \\
(6)\end{array}$ \\
\hline Mother-in-law worked & $\begin{array}{l}0.068^{* *} \\
(0.031)\end{array}$ & $\begin{array}{c}0.082^{*} \\
(0.046)\end{array}$ & $\begin{array}{l}1.089 \\
(0.927)\end{array}$ & $\begin{array}{l}1.801 \\
(0.138)\end{array}$ & $\begin{array}{l}0.369^{* *} \\
(0.178)\end{array}$ & $\begin{array}{l}0.645^{* *} \\
(0.285)\end{array}$ \\
\hline Own mother worked & $\begin{array}{c}0.013 \\
(0.032)\end{array}$ & $\begin{array}{c}0.034 \\
(0.045)\end{array}$ & $\begin{array}{l}-0.138 \\
(1.013)\end{array}$ & $\begin{array}{l}1.766 \\
(1.449)\end{array}$ & $\begin{array}{l}0.364^{* *} \\
(0.179)\end{array}$ & $\begin{array}{c}0.452 \\
(0.296)\end{array}$ \\
\hline Full set of controls & $\checkmark$ & $\checkmark$ & $\checkmark$ & $\checkmark$ & $\checkmark$ & $\checkmark$ \\
\hline $\begin{array}{l}\text { Observations } \\
R \text {-squared }\end{array}$ & $\begin{array}{r}9655 \\
0.144\end{array}$ & $\begin{array}{r}6340 \\
0.116\end{array}$ & $\begin{array}{l}8338 \\
0.256\end{array}$ & $\begin{array}{c}5436 \\
0.193\end{array}$ & $\begin{array}{r}9655 \\
0.208\end{array}$ & $\begin{array}{r}6340 \\
0.164\end{array}$ \\
\hline \multirow[t]{2}{*}{ Panel B } & \multicolumn{6}{|c|}{ Local culture and labour market effects } \\
\hline & (1) & $(2)$ & (3) & (4) & $(5)$ & (6) \\
\hline Mother-in-law worked & $\begin{array}{l}0.069^{* * *} \\
(0.023)\end{array}$ & $\begin{array}{l}0.070^{* * *} \\
(0.022)\end{array}$ & $\begin{array}{l}1.374^{*} \\
(0.709)\end{array}$ & $\begin{array}{l}1.449^{* *} \\
(0.644)\end{array}$ & $\begin{array}{l}0.388^{* * *} \\
(0.142)\end{array}$ & $\begin{array}{l}0.378^{* * *} \\
(0.132)\end{array}$ \\
\hline Own mother worked & $\begin{array}{c}0.020 \\
(0.023)\end{array}$ & $\begin{array}{c}0.026 \\
(0.022)\end{array}$ & $\begin{array}{c}0.456 \\
(0.710)\end{array}$ & $\begin{array}{c}0.602 \\
(0.640)\end{array}$ & $\begin{array}{l}0.317^{* *} \\
(0.142)\end{array}$ & $\begin{array}{l}0.336^{* *} \\
(0.131)\end{array}$ \\
\hline $\begin{array}{l}\text { Average participation of } \\
\text { peers' mothers in county }\end{array}$ & $\begin{array}{c}0.091 \\
(0.081)\end{array}$ & & $\begin{array}{l}2.442 \\
(2.497)\end{array}$ & & $\begin{array}{c}0.051 \\
(0.474)\end{array}$ & \\
\hline $\begin{array}{l}\text { Full set of controls } \\
\text { NUTS } 2 \text { fixed effects }\end{array}$ & $\checkmark$ & $\begin{array}{l}\sqrt{2} \\
\checkmark\end{array}$ & $\checkmark$ & $\begin{array}{l}-1 \\
d\end{array}$ & $\checkmark$ & $\begin{array}{l}-1 \\
\checkmark\end{array}$ \\
\hline $\begin{array}{l}\text { Observations } \\
R \text {-squared }\end{array}$ & $\begin{array}{l}22814 \\
0.129\end{array}$ & $\begin{array}{l}22814 \\
0.139\end{array}$ & $\begin{array}{l}19913 \\
0.262\end{array}$ & $\begin{array}{l}19913 \\
0.277\end{array}$ & $\begin{array}{l}22814 \\
0.188\end{array}$ & $\begin{array}{l}22814 \\
0.199\end{array}$ \\
\hline \multirow[t]{2}{*}{ Panel C } & \multicolumn{6}{|c|}{ Follow-up subsample } \\
\hline & (1) & $(2)$ & (3) & (4) & $(5)$ & (6) \\
\hline Mother-in-law worked & $\begin{array}{l}0.133^{* * *} \\
(0.040)\end{array}$ & $\begin{array}{l}0.114^{* * *} \\
(0.043)\end{array}$ & $\begin{array}{l}2.923^{* *} \\
(1.377)\end{array}$ & $\begin{array}{l}2.717^{* *} \\
(1.166)\end{array}$ & $\begin{array}{l}0.752^{* *} \\
(0.309)\end{array}$ & $\begin{array}{l}0.800^{* * *} \\
(0.260)\end{array}$ \\
\hline Full set of controls & & $\checkmark$ & & $\checkmark$ & & $\checkmark$ \\
\hline $\begin{array}{l}\text { Observations } \\
R \text {-squared }\end{array}$ & $\begin{array}{c}3618 \\
0.150\end{array}$ & $\begin{array}{c}3618 \\
0.272\end{array}$ & $\begin{array}{c}3276 \\
0.293\end{array}$ & $\begin{array}{c}3276 \\
0.504\end{array}$ & $\begin{array}{c}3618 \\
0.199\end{array}$ & $\begin{array}{c}3618 \\
0.360\end{array}$ \\
\hline
\end{tabular}

Note: Columns (1) and (2) report marginal effects evaluated at the mean of the independent variable (probit estimation). Regressions in Columns (1), (3) and (5) of Panel A are estimates in the sample where the mother-in-law lives far away and in Columns (2), (4) and (6) of Panel A in a sample where the mother-in-law died already. In Panel $\mathrm{B}$, we control for the average participation rate of peer's mothers within the county and NUTS-2 fixed effects. Panel $\mathrm{C}$ shows estimates in the sub-sample of partners we can directly observe during their childhood. Control variables in Panel A and B are shown in Table A1. Control variables in Panel C are depicted in Table A3. Regressions are weighted using provided survey weights. ${ }^{*} p<0.1,{ }^{* *} p<0.05,{ }^{* * *} p<0.01$.

Source: SOEP v.33, Statistisches Bundesamt (2019), own calculation. 


\section{References}

Andreoni, J., Brown, E. and Rischall, I. (2003). Charitable giving by married couples who decides and why does it matter?, Journal of Human Resources 38(1): 111-133.

Antecol, H. (2000). An examination of cross-country differences in the gender gap in labor force participation rates, Labour Economics 7(4): 409-426.

Attanasio, O., Low, H. and Sánchez-Marcos, V. (2008). Explaining changes in female labor supply in a life-cycle model, The American Economic Review pp. 1517-1552.

Bandura, A. (1977). Self-efficacy: toward a unifying theory of behavioral change., Psychological review 84(2): 191.

Bauernschuster, S. and Rainer, H. (2012). Political regimes and the family: How sex-role attitudes continue to differ in reunified Germany, Journal of Population Economics 25(1): 5-27.

Bisin, A. and Verdier, T. (2000). "Beyond the melting pot": Cultural transmission, marriage, and the evolution of ethnic and religious traits, The Quarterly Journal of Economics 115(3): 955-988.

Bittman, M., England, P., Sayer, L., Folbre, N. and Matheson, G. (2003). When does gender trump money? bargaining and time in household work, American Journal of sociology 109(1): 186-214.

Bütikofer, A. (2013). Revisiting "mothers and sons'" preference formation and the female labor force in Switzerland, Labour Economics 20: 82-91.

Campa, P. and Serafinelli, M. (forthcoming). Politico-economic regimes and attitudes: Female workers under state-socialism, Review of Economics and Statistics .

Charles, K., Guryan, J. and Pan, J. (2009). Sexism and women's labor market outcomes, Working Paper, University of Chicago .

Charles, M. and Grusky, D. B. (2004). Occupational ghettos: The worldwide segregation of women and men, Vol. 200, Stanford University Press Stanford, CA.

Collins, C. (2019). Making motherhood work: How women manage careers and caregiving, Princeton: Princeton University Press.

Coltrane, S. (2000). Research on household labor: Modeling and measuring the social embeddedness of routine family work, Journal of Marriage and family 62(4): 1208-1233.

Ebbinghaus, H. (1894). Memory: A contribution to experimental psychology, New York: Dover.

Farre, L. and Vella, F. (2013). The intergenerational transmission of gender role attitudes and its implications for female labour force participation, Economica 80(318): 219-247.

Fernández, R. (2013). Cultural change as learning: The evolution of female labor force participation over a century, The American Economic Review 103(1): 472-500.

Fernandez, R. and Fogli, A. (2009). Culture: An empirical investigation of beliefs, work, and fertility, American Economic Journal: Macroeconomics 1(1): 146-177.

Fernández, R., Fogli, A. and Olivetti, C. (2004). Mothers and sons: Preference formation and female labor force dynamics, The Quarterly Journal of Economics 119(4): 1249-1299.

Fernández, R. (2011). Does culture matter?, in J. Benhabib, A. Bisin and M. O. Jackson (eds), Handbook of Social Economics, Vol. 1, North-Holland, chapter 11, pp. 481 - 510.

Fogli, A. and Veldkamp, L. (2011). Nature or nurture? learning and the geography of female labor force participation, Econometrica 79(4): 1103-1138.

Galor, O. and Weil, D. (1996). The gender gap, fertility, and growth, American Economic Review 86(3): $374-87$.

Gangl, M. and Ziefle, A. (2009). Motherhood, labor force behavior, and women's careers: An empirical assessment of the wage penalty for motherhood in britain, germany, and the united states, Demography 46(2): 341-369.

GESIS - Leibniz-Institut für Sozialwissenschaften (2016). Allgemeine Bevölkerungsumfrage der Sozialwissenschaften ALLBUScompact - Kumulation 1980 - 2014. 
Goebel, J., Grabka, M. M., Liebig, S., Kroh, M., Richter, D., Schröder, C. and Schupp, J. (2019). The German Socio-Economic Panel (SOEP), Jahrbücher für Nationalökonomie und Statistik 239(2): 345-360.

Goldin, C. (1990). The gender gap: An economic history of American women, New York: Cambridge University Press.

Goldin, C. and Katz, L. F. (2002). The power of the pill: Oral contraceptives and women's career and marriage decisions, Journal of Political Economy 110(4): 730-770.

Greenwood, J., Seshadri, A. and Yorukoglu, M. (2005). Engines of liberation, The Review of Economic Studies 72(1): 109-133.

Hakim, C. (2000). Work-lifestyle choices in the 21st century: Preference theory, London: Routledge.

Hakim, C. (2002). Do lifestyle preferences explain the pay gap? paper presented to the gender research forum conference on the gender pay and productivity gap.

Hiedemann, B. (1998). A stackelberg model of social security acceptance decisions in dual career households, Journal of Economic Behavior \& Organization 34(2): 263-278.

Hill, J. P. and Lynch, M. E. (1983). The intensification of gender-related role expectations during early adolescence, Girls at puberty, Springer, pp. 201-228.

Inglehart, R. and Norris, P. (2003). Rising tide: Gender equality and cultural change around the world, New York: Cambridge University Press.

Iversen, T. and Rosenbluth, F. (2006). The political economy of gender: Explaining cross-national variation in the gender division of labor and the gender voting gap, American Journal of Political Science 50(1): 1-19.

Kawaguchi, D. and Miyazaki, J. (2009). Working mothers and sons' preferences regarding female labor supply: Direct evidence from stated preferences, Journal of Population Economics 22(1): 115-130.

Kleven, H. and Landais, C. (2017). Gender inequality and economic development: fertility, education and norms, Economica 84(334): 180-209.

Kleven, H., Landais, C., Posch, J., Steinhauer, A. and Zweimüller, J. (2019). Child penalties across countries: Evidence and explanations, AEA Papers and Proceedings, Vol. 109, pp. 122-26.

Kleven, H., Landais, C. and Søgaard, J. E. (2019). Children and gender inequality: Evidence from denmark, American Economic Journal: Applied Economics 11(4): 181-209.

Knowles, J. A. (2012). Why are married men working so much? an aggregate analysis of intrahousehold bargaining and labour supply, Review of Economic Studies 80(3): 1055-1085.

Kremer, M. (2007). How welfare states care: Culture, gender and parenting in Europe, Utrecht: Amsterdam University Press.

Løken, K. V., Lommerud, K. E. and Lundberg, S. (2013). Your place or mine? on the residence choice of young couples in norway, Demography 50(1): 285-310.

Lundberg, S., Startz, R. and Stillman, S. (2003). The retirement-consumption puzzle: a marital bargaining approach, Journal of Public Economics 87(5-6): 1199-1218.

Morrill, M. S. and Morrill, T. (2013). Intergenerational links in female labor force participation, Labour Economics 20: 38-47.

Mota, N., Patacchini, E. and Rosenthal, S. S. (2016). Neighborhood effects, peer classification, and the decision of women to work, Technical report, IZA Discussion Papers.

Nicoletti, C., Salvanes, K. G. and Tominey, E. (2019). The familiy peer effect on mothers labor supply, American Economic Journal: Applied Economics .

OECD (2019). OECD Family Data Base, OECD Publishing, Paris.

Olivetti, C. (2006). Changes in women's hours of market work: The role of returns to experience, Review of Economic Dynamics 9(4): 557-587.

Olivetti, C., Patacchini, E. and Zenou, Y. (forthcoming). Mothers, friends and gender identity, Journal of the European Economic Association . 
Ondrich, J., Spiess, C. K., Yang, Q. and Wagner, G. G. (2003). The liberalization of maternity leave policy and the return to work after childbirth in germany, Review of Economics of the Household 1(1-2): 77-110.

Powell, B. and Steelman, L. C. (1982). Testing an undertested comparison: Maternal effects on sons' and daughters' attitudes toward women in the labor force, Journal of Marriage and the Family pp. 349-355.

Rosenfeld, R. A., Trappe, H. and Gornick, J. C. (2004). Gender and work in germany: Before and after reunification, Annual Review of Sociology 30: 103-124.

Schober, P. S. and Spiess, C. K. (2013). Early childhood education activities and care arrangements of disadvantaged children in germany, Child Indicators Research 6(4): 709-735.

Spiess, C. K. and Wrohlich, K. (2008). The parental leave benefit reform in germany: costs and labour market outcomes of moving towards the nordic model, Population Research and Policy Review 27(5): 575.

Statistisches Bundesamt (2017). Bevölkerung und Erwerbstätigkeit, Statistisches Bundesamt, Wiesbaden.

Statistisches Bundesamt (2018a). 10 \% der Frauen hatten 2017 einen höheren Bildungsstand als ihr Partner, Statistisches Bundesamt, Wiesbaden.

Statistisches Bundesamt (2018b). Bevölkerung und Erwerbstätigkeit, Statistisches Bundesamt, Wiesbaden.

Statistisches Bundesamt (2019). Regionaldatenbank Statistische Ämter des Bundes und der Länder. URL: https://www.regionalstatistik.de/genesis/online/

Steiner, V. and Wrohlich, K. (2004). Household taxation, income splitting and labor supply incentives-a microsimulation study for germany, CESifo Economic Studies 50(3): 541-568.

Sullivan, O. (2006). Changing gender relations, changing families: Tracing the pace of change over time, New York: Rowman \& Littlefield.

Unterhofer, U. and Wrohlich, K. (2017). Fathers, parental leave and gender norms.

Wegener, B. (1984). Gibt es Sozialprestige? Konstruktion und Validität der Magnitude-PrestigeSkala, Vol. 1984/02.

Williams, J. (2010). Reshaping the work-family debate: Why men and class matter, Cambridge: Harvard University Press.

Zoch, G. and Schober, P. S. (2018). Public child-care expansion and changing gender ideologies of parents in germany, Journal of Marriage and Family 80(4): 1020-1039. 


\section{Appendix}

Figure A1: Comparison of mother's labour force participation in SOEP to administrative statistics

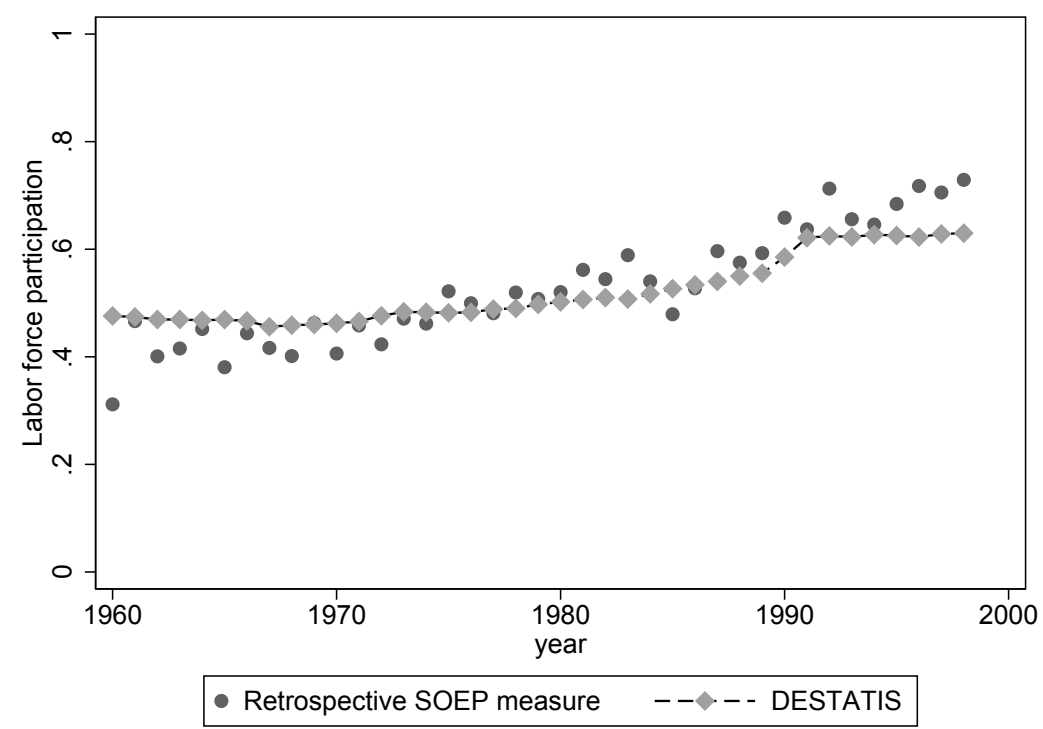

Notes: The figure shows female labour force participation in Germany (1960 - 2000) based on administrative data (Statistisches Bundesamt; 2018) and the retrospective SOEP measure of mothers' labour force participation at age 15 .

Source: SOEP v.33, Statistisches Bundesamt (2019), own calculation. 
Figure A2: Distribution of working hours and gross labour income

(a) weekly working hours

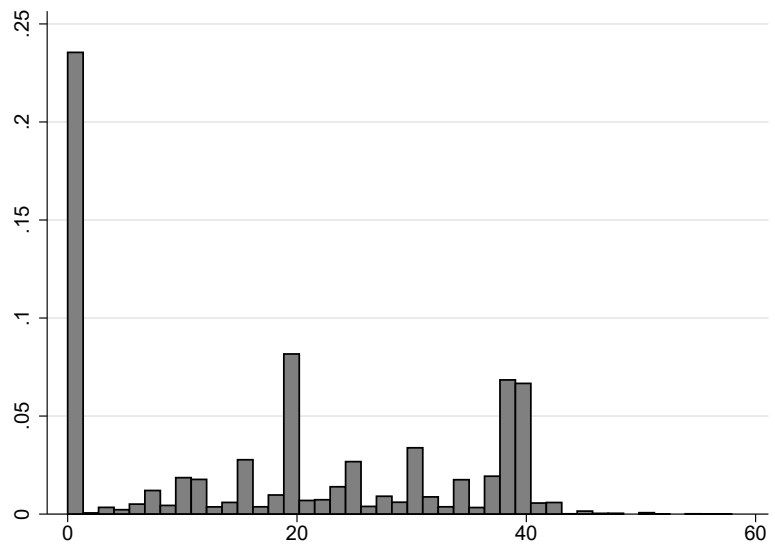

(c) log gross monthly labour income

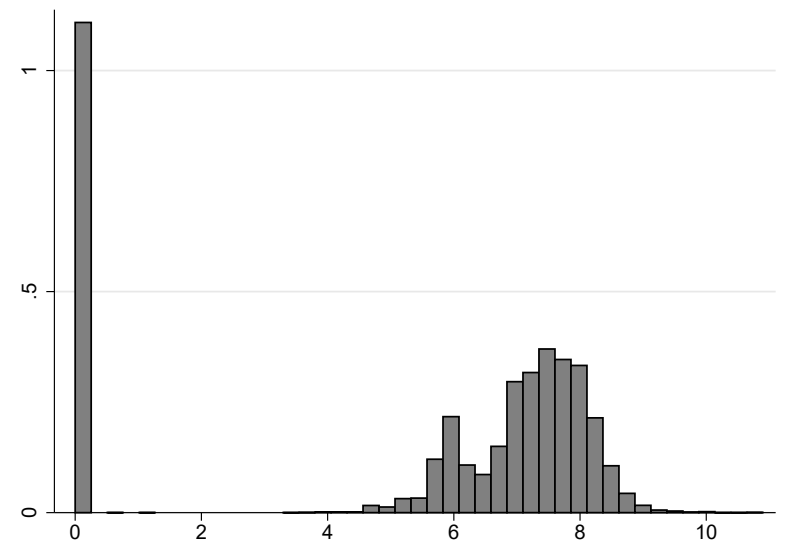

(b) weekly working hours relative to partner

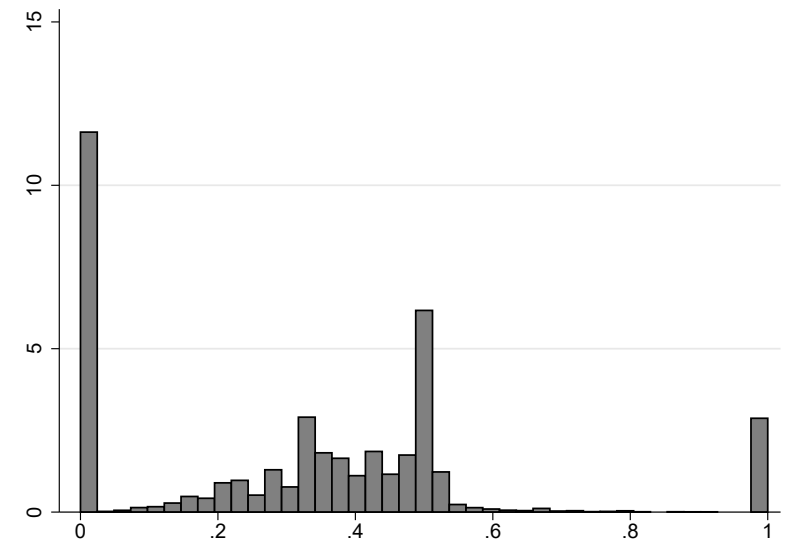

(d) log gross monthly labour income relative to partner

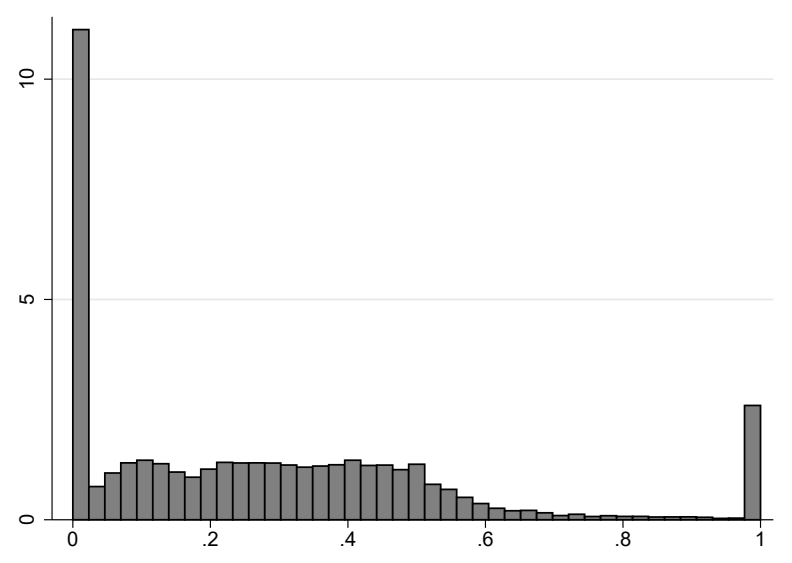

Note: The figures show the distribution of weekly working hours and gross labour income (relative to the partner).

Source: SOEP v.33, Statistisches Bundesamt (2019), own calculation. 
Figure A3: Working hours

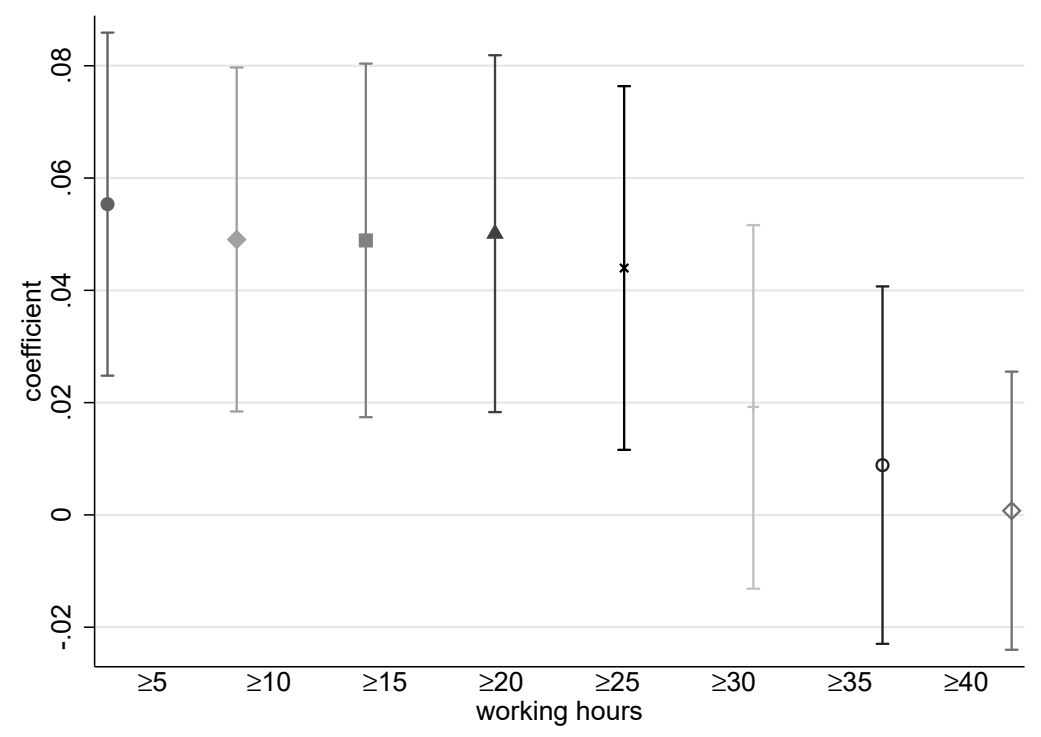

Notes: The figure shows intergenerational (mother-in-law) coefficients using different categories (dummies) of working hours as outcomes (i.e. all those who work 5 hours or more are coded as 1; all those who work 10 hours or more are coded as one; etc.) All regression are weighted using provided survey weights and include the full set of controls shown in Table A1.

Source: SOEP v.33, Statistisches Bundesamt (2019), own calculation. 
Figure A4: Labour force participation over life cycle

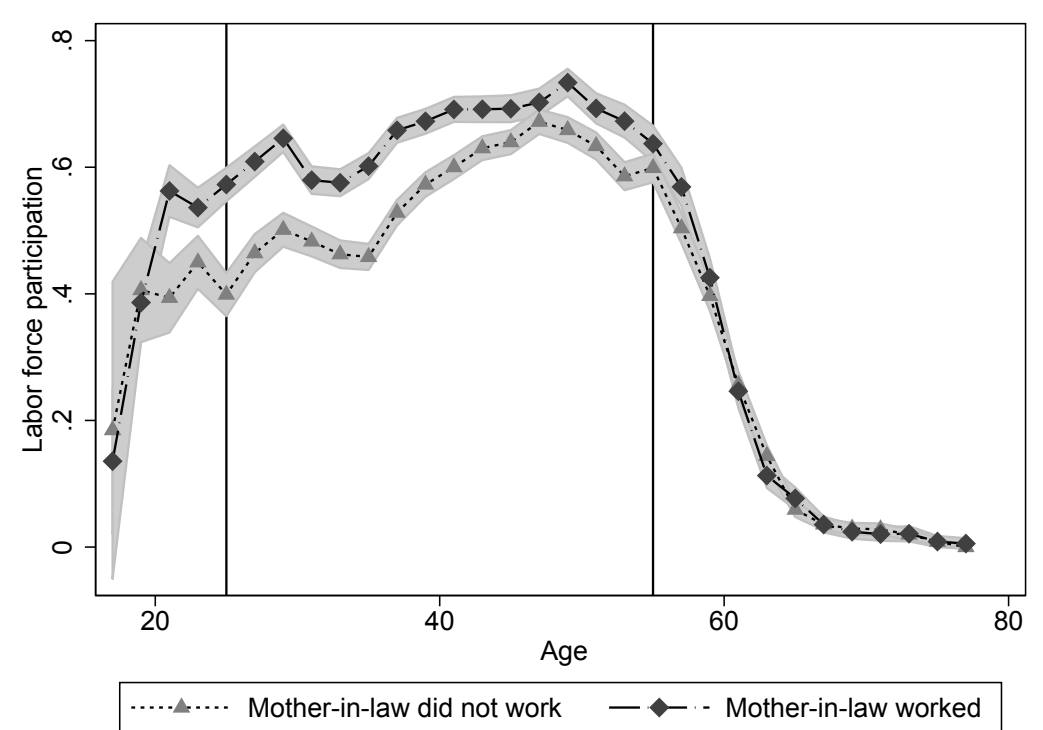

Notes:The figure shows female labour force participation over the life cycle (two year age bins) by mother-in-law's working status. The age groups within the vertical lines are included in our main estimation sample. $95 \%$ confidence intervals.

Source: SOEP v.33, Statistisches Bundesamt (2019), own calculation. 
Figure A5: Labour market outcomes over the life cycle

(a) labour force participation

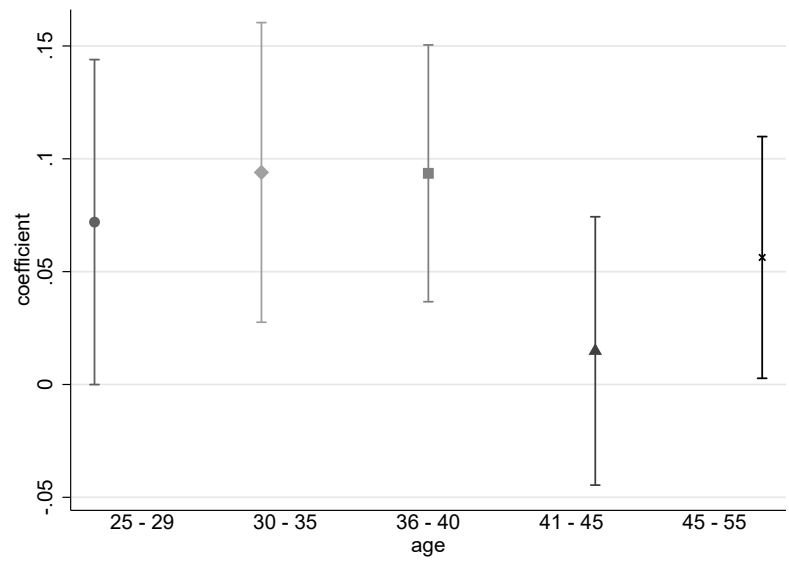

(b) weekly working hours

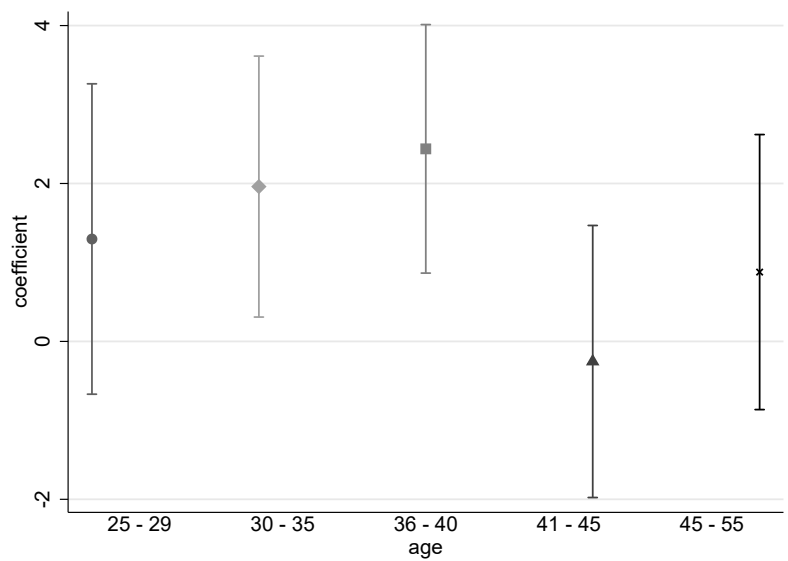

(c) log gross monthly labour income

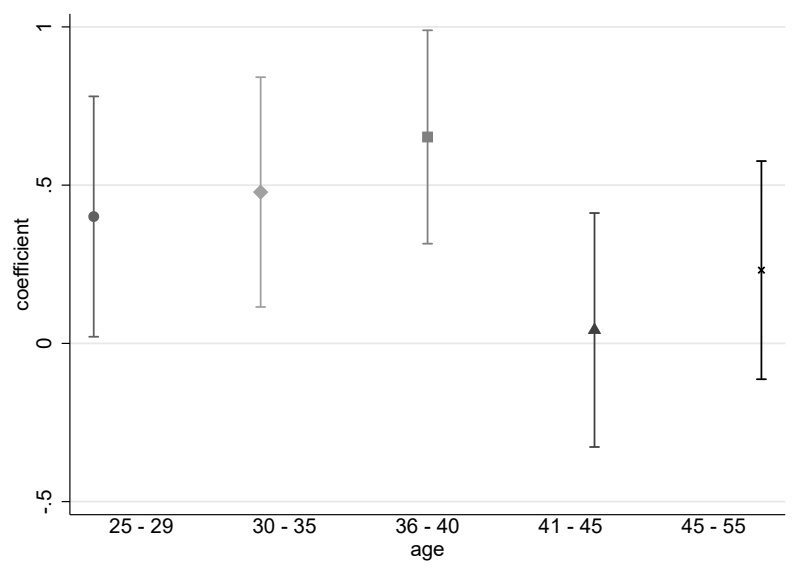

Note: The figures shows intergenerational (mother-in-law) coefficients estimates for women in different age subgroups. Marginal effects from probit estimation in (a) are calculated at the mean of the independent variable. All regression are weighted using provided survey weights and include the full set of controls shown in Table A1.

Source: SOEP v.33, Statistisches Bundesamt (2019), own calculation. 

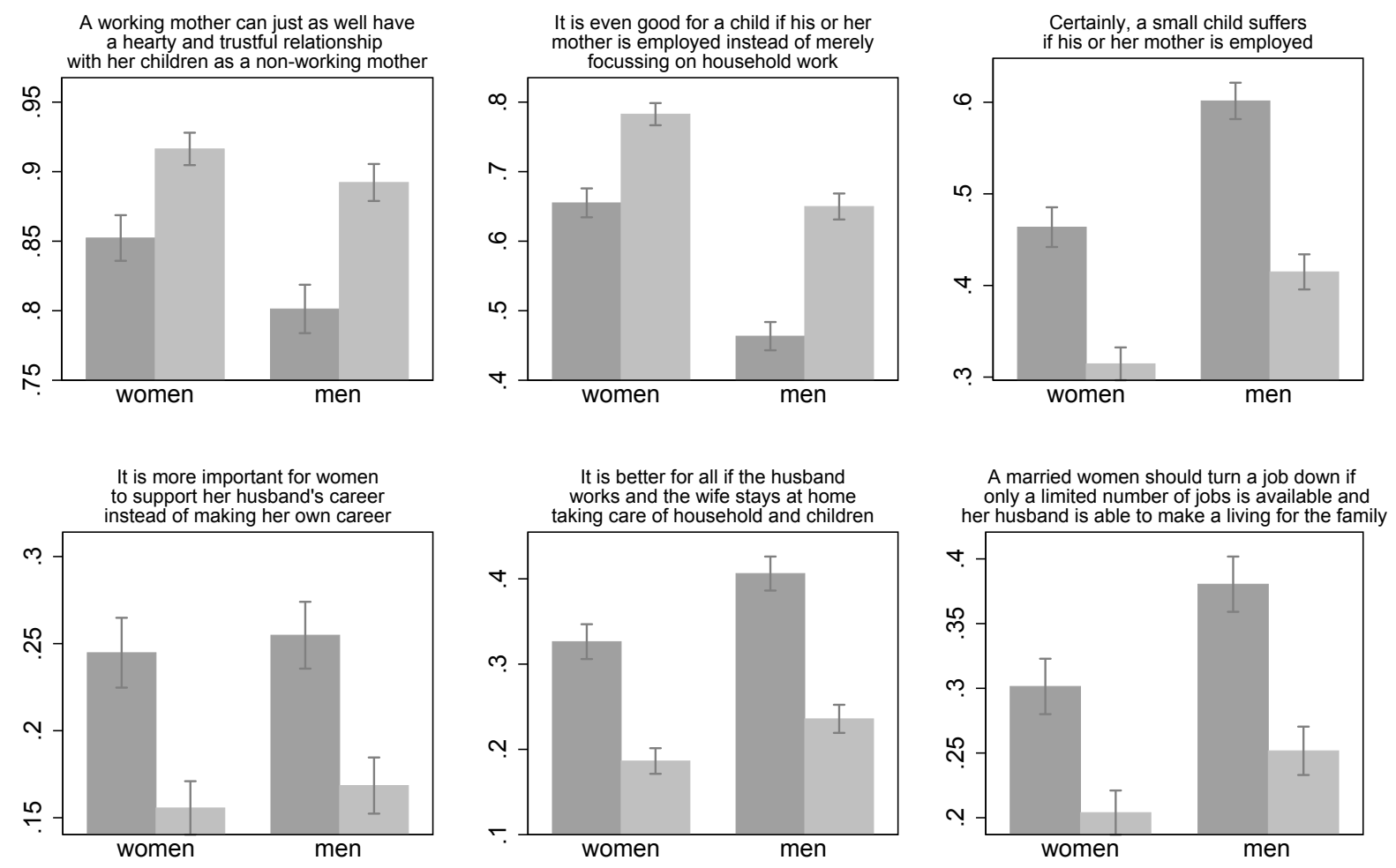

Mother did not work

Mother worked

Figure A6: The histograms show the fraction of women and men agreeing to a statement by own mother's working status.

Source: ALLBUS 2004, 2008, 2012 and 2016, own calculation. 
Figure A7: Placebo estimates for rematched couples within regions

(a) labour force participation

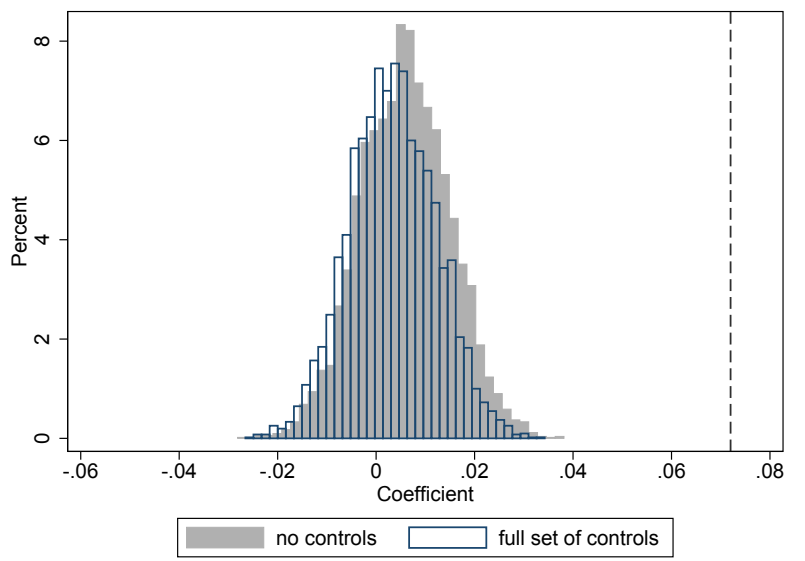

(b) weekly working hours

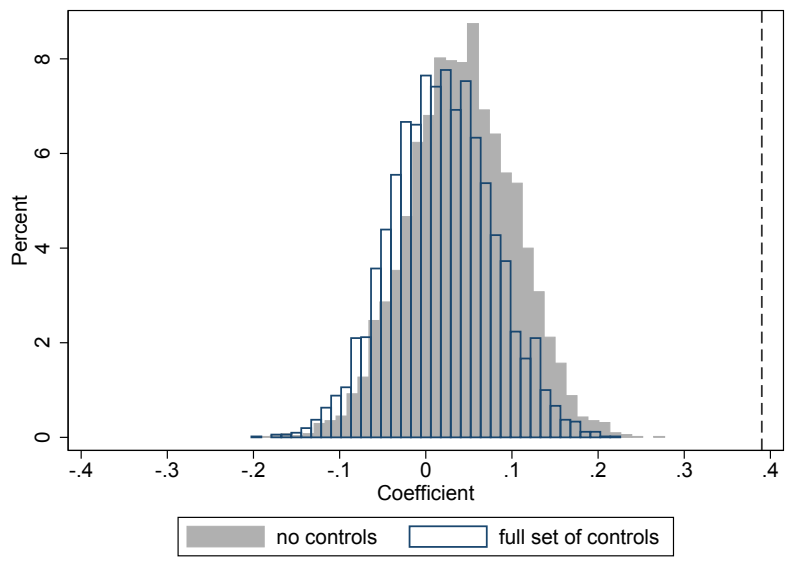

(c) log gross monthly labour income

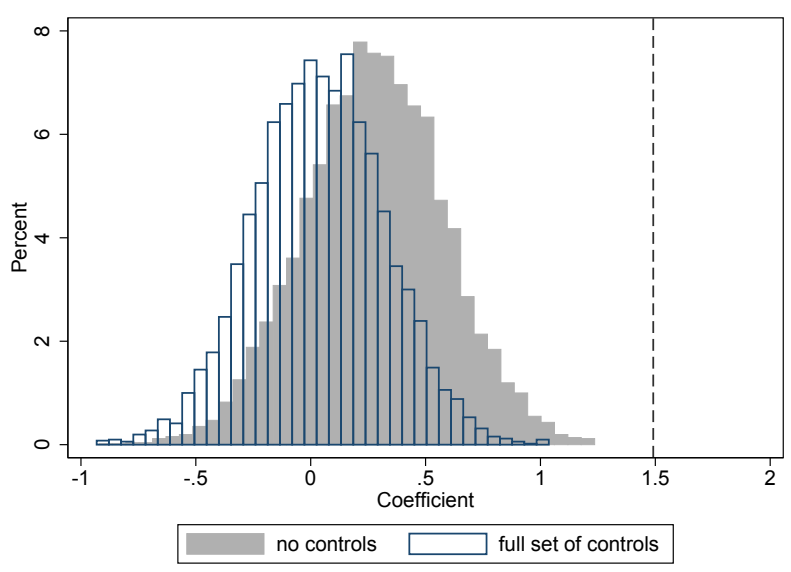

Note: The figures show the distribution of the $\beta_{1}$ coefficients from equation (1) estimated in the samples of 5000 independent random rematches of couples within a NUTS-2 region, i.e. the correlations between the labour market outcomes of women and their randomly matched mothers-in-law. The distributions are shown separately when estimating equation (1) without controls and when including the full set of controls shown in Table A1. The vertical line denotes our main $\beta_{1}$ estimate from Table 1 and Table 2. Marginal effects in (a) are calculated at the mean of the independent variables. Regressions are weighted using provided survey weights.

Source: SOEP v.33, Statistisches Bundesamt (2019), own calculation. 
Table A1: Descriptive statistics SOEP

\begin{tabular}{|c|c|c|c|c|}
\hline & Mean & Std. Dev. & Min. & Max. \\
\hline \multicolumn{5}{|l|}{ Independent variables: } \\
\hline Own mother worked & 0.57 & 0.49 & 0.00 & 1.00 \\
\hline Mother-in-law worked & 0.50 & 0.50 & 0.00 & 1.00 \\
\hline \multicolumn{5}{|l|}{ Control variables: } \\
\hline \multicolumn{5}{|l|}{ Own characteristics } \\
\hline Age & 41.42 & 8.31 & 25.00 & 55.00 \\
\hline Years of education & 12.63 & 2.70 & 7.00 & 18.00 \\
\hline Protestant & 0.38 & 0.49 & 0.00 & 1.00 \\
\hline Catholic & 0.37 & 0.48 & 0.00 & 1.00 \\
\hline Other religion & 0.08 & 0.27 & 0.00 & 1.00 \\
\hline No religion & 0.17 & 0.37 & 0.00 & 1.00 \\
\hline Married & 0.85 & 0.36 & 0.00 & 1.00 \\
\hline \# children & 0.86 & 1.00 & 0.00 & 8.00 \\
\hline$\#$ children $\leq 6$ years & 0.35 & 0.66 & 0.00 & 5.00 \\
\hline \multicolumn{5}{|l|}{ Partner characteristics } \\
\hline Age & 44.46 & 9.24 & 19.00 & 79.00 \\
\hline Gross monthly income & 3358.08 & 2942.02 & 0.00 & 159905.00 \\
\hline Years of education & 12.67 & 2.85 & 7.00 & 18.00 \\
\hline Protestant & 0.33 & 0.47 & 0.00 & 1.00 \\
\hline Catholic & 0.36 & 0.48 & 0.00 & 1.00 \\
\hline Other religion & 0.07 & 0.25 & 0.00 & 1.00 \\
\hline No religion & 0.24 & 0.43 & 0.00 & 1.00 \\
\hline \multicolumn{5}{|l|}{ Own parents characteristics } \\
\hline Mother primary education & 0.05 & 0.22 & 0.00 & 1.00 \\
\hline Mother secondary education & 0.67 & 0.47 & 0.00 & 1.00 \\
\hline Mother tertiary education & 0.28 & 0.45 & 0.00 & 1.00 \\
\hline Father primary education & 0.04 & 0.19 & 0.00 & 1.00 \\
\hline Father secondary education & 0.64 & 0.48 & 0.00 & 1.00 \\
\hline Father tertiary education & 0.32 & 0.47 & 0.00 & 1.00 \\
\hline Father job prestige & 56.09 & 27.38 & 30.10 & 216.00 \\
\hline \multicolumn{5}{|l|}{ Parents-in-law characteristics } \\
\hline Mother-in-law primary education & 0.05 & 0.22 & 0.00 & 1.00 \\
\hline Mother-in-law secondary education & 0.71 & 0.45 & 0.00 & 1.00 \\
\hline Mother-in-law tertiary education & 0.24 & 0.43 & 0.00 & 1.00 \\
\hline Father-in-law primary education & 0.04 & 0.19 & 0.00 & 1.00 \\
\hline Father-in-law secondary education & 0.67 & 0.47 & 0.00 & 1.00 \\
\hline Father-in-law tertiary education & 0.29 & 0.45 & 0.00 & 1.00 \\
\hline Father-in-law job prestige & 56.86 & 29.35 & 30.10 & 216.00 \\
\hline \multicolumn{5}{|l|}{ Regional characteristics } \\
\hline$<20,000$ Inhabitants & 0.39 & 0.49 & 0.00 & 1.00 \\
\hline $20,000-100,000$ Inhabitants & 0.28 & 0.45 & 0.00 & 1.00 \\
\hline$>100,000$ Inhabitants & 0.33 & 0.47 & 0.00 & 1.00 \\
\hline Unemployment rate & 7.70 & 3.28 & 1.20 & 23.70 \\
\hline Employment rate & 50.44 & 4.54 & 36.70 & 64.30 \\
\hline GDP per capita & 1585.93 & 220.71 & 1080.50 & 3466.90 \\
\hline Share of foreigners & 10.01 & 4.88 & 2.10 & 32.30 \\
\hline Size of county $\left(\mathrm{km}^{2}\right)$ & 809.77 & 544.82 & 35.70 & 2882.06 \\
\hline Day care ratios $<3$ years & 14.01 & 10.29 & 0.00 & 44.10 \\
\hline Day care ratios $\geq 3$ years & 87.42 & 8.10 & 54.26 & 108.80 \\
\hline
\end{tabular}

Note: The sample includes all cohabiting women aged between 25 and 50 living in West Germany. Descriptive statistics are weighted using provided survey weights.

Source: SOEP v33, Statistisches Bundesamt (2019), own calculation. 
Table A2: Descriptive statistics ALLBUS

\begin{tabular}{|c|c|c|c|c|}
\hline & Mean & Std. Dev. & Min. & Max. \\
\hline \multicolumn{5}{|l|}{ Independent variables: } \\
\hline Mother-in-law worked & 0.48 & 0.50 & 0.00 & 1.00 \\
\hline \multicolumn{5}{|l|}{ Control variables: } \\
\hline \multicolumn{5}{|l|}{ Own characteristics } \\
\hline Age & 41.46 & 8.66 & 25.00 & 55.00 \\
\hline Primary education & 0.09 & 0.28 & 0.00 & 1.00 \\
\hline Secondary education & 0.53 & 0.50 & 0.00 & 1.00 \\
\hline Tertiary education & 0.38 & 0.49 & 0.00 & 1.00 \\
\hline Children & 0.78 & 0.42 & 0.00 & 1.00 \\
\hline \multicolumn{5}{|l|}{ Partner characteristics } \\
\hline Age & 44.55 & 9.62 & 19.00 & 83.00 \\
\hline Income (in categories) & 13.81 & 4.61 & 0.00 & 22.00 \\
\hline Primary education & 0.05 & 0.22 & 0.00 & 1.00 \\
\hline Secondary education & 0.47 & 0.50 & 0.00 & 1.00 \\
\hline Tertiary education & 0.48 & 0.50 & 0.00 & 1.00 \\
\hline Protestant & 0.29 & 0.45 & 0.00 & 1.00 \\
\hline Catholic & 0.25 & 0.43 & 0.00 & 1.00 \\
\hline Other religion & 0.07 & 0.25 & 0.00 & 1.00 \\
\hline No religion & 0.40 & 0.49 & 0.00 & 1.00 \\
\hline \multicolumn{5}{|l|}{ Parents-in-law characteristics } \\
\hline Mother-in-law primary education & 0.32 & 0.47 & 0.00 & 1.00 \\
\hline Mother-in-law secondary education & 0.52 & 0.50 & 0.00 & 1.00 \\
\hline Mother-in-law tertiary education & 0.15 & 0.36 & 0.00 & 1.00 \\
\hline Father-in-law primary education & 0.14 & 0.35 & 0.00 & 1.00 \\
\hline Father-in-law secondary education & 0.58 & 0.49 & 0.00 & 1.00 \\
\hline Father-in-law tertiary education & 0.28 & 0.45 & 0.00 & 1.00 \\
\hline \multicolumn{5}{|l|}{ Regional characteristics } \\
\hline$<20,000$ Inhabitants & 0.64 & 0.48 & 0.00 & 1.00 \\
\hline 20,000-100,000 Inhabitants & 0.10 & 0.30 & 0.00 & 1.00 \\
\hline$>100.000$ Inhabitants & 0.26 & 0.44 & 0.00 & 1.00 \\
\hline
\end{tabular}

Note: The sample includes all cohabiting women aged between 25 and 50 living in West Germany.

Source: ALLBUS 2002 - 2016, own calculation. 
Table A3: Descriptive statistics SOEP - follow up subsample

\begin{tabular}{|c|c|c|c|c|}
\hline & Mean & Std. Dev. & Min. & Max. \\
\hline \multicolumn{5}{|l|}{ Independent variables: } \\
\hline Mother-in-law worked & 0.52 & 0.50 & 0.00 & 1.00 \\
\hline \multicolumn{5}{|l|}{ Control variables: } \\
\hline \multicolumn{5}{|l|}{ Own characteristics } \\
\hline Age & 34.04 & 6.15 & 25.00 & 55.00 \\
\hline Years of education & 12.39 & 2.59 & 7.00 & 18.00 \\
\hline Married & 0.78 & 0.41 & 0.00 & 1.00 \\
\hline \# children & 1.11 & 0.96 & 0.00 & 5.00 \\
\hline$\#$ children $\leq 6$ years & 0.65 & 0.75 & 0.00 & 3.00 \\
\hline \multicolumn{5}{|l|}{ Partner characteristics } \\
\hline Age & 35.05 & 5.35 & 19.00 & 50.00 \\
\hline Income & 7.67 & 1.62 & 0.00 & 9.85 \\
\hline Years of education & 12.74 & 2.73 & 7.00 & 18.00 \\
\hline Protestant & 0.26 & 0.44 & 0.00 & 1.00 \\
\hline Catholic & 0.38 & 0.48 & 0.00 & 1.00 \\
\hline Other religon & 0.15 & 0.36 & 0.00 & 1.00 \\
\hline No religon & 0.21 & 0.41 & 0.00 & 1.00 \\
\hline \multicolumn{5}{|l|}{ Parents-in-law characteristics } \\
\hline Mother-in-law years of education & 10.68 & 2.26 & 7.00 & 18.00 \\
\hline Father-in-law years of education & 11.51 & 2.57 & 7.00 & 18.00 \\
\hline Log household income & 7.10 & 0.46 & 5.74 & 8.73 \\
\hline House owner & 0.54 & 0.50 & 0.00 & 1.00 \\
\hline \multicolumn{5}{|l|}{ Regional characteristics } \\
\hline$<20,000$ Inhabitants & 0.44 & 0.50 & 0.00 & 1.00 \\
\hline 20,000-100,000 Inhabitants & 0.27 & 0.44 & 0.00 & 1.00 \\
\hline$>100,000$ Inhabitants & 0.29 & 0.45 & 0.00 & 1.00 \\
\hline Unemployment rate & 7.84 & 3.24 & 2.00 & 20.10 \\
\hline Employment rate & 50.58 & 4.40 & 38.30 & 64.30 \\
\hline GDP per capita & 1574.81 & 229.14 & 1113.10 & 3466.90 \\
\hline Share of foreigners & 9.74 & 4.87 & 2.30 & 32.30 \\
\hline Size of county $\left(\mathrm{km}^{2}\right)$ & 801.69 & 507.21 & 44.89 & 2882.06 \\
\hline Day care ratios $<3$ years & 14.29 & 11.33 & 0.00 & 46.20 \\
\hline Day care ratios $\geq 3$ years & 87.06 & 8.13 & 56.77 & 105.22 \\
\hline
\end{tabular}

Note: The sample includes all cohabiting couples living in West Germany where the women is aged between 25 and 50. Descriptive statistics are weighted using provided survey weights.

Source: SOEP v33, Statistisches Bundesamt (2019), own calculation. 
Table A4: Female labour force participation - marginal effects of controls

\begin{tabular}{|c|c|c|c|c|c|c|c|}
\hline & (1) & $(2)$ & (3) & (4) & $(5)$ & (6) & (7) \\
\hline Mean of dep. variable & 0.626 & 0.626 & 0.626 & 0.626 & 0.626 & 0.626 & 0.626 \\
\hline Partner's age & $\begin{array}{l}0.026 * * * \\
(0.008)\end{array}$ & & $\begin{array}{l}0.027 * * \\
(0.010)\end{array}$ & $\begin{array}{l}0.030^{* * *} \\
(0.011)\end{array}$ & $\begin{array}{l}0.026^{* * * *} \\
(0.008)\end{array}$ & $\begin{array}{l}0.030^{* * *} \\
(0.011)\end{array}$ & $\begin{array}{l}0.031 * * * \\
(0.011)\end{array}$ \\
\hline Partner's age squ. & $\begin{array}{l}-0.000^{* *} \\
(0.000)\end{array}$ & & $\begin{array}{l}-0.000 * \\
(0.000)\end{array}$ & $\begin{array}{l}-0.000 * * \\
(0.000)\end{array}$ & $\begin{array}{l}-0.000 * * \\
(0.000)\end{array}$ & $\begin{array}{l}-0.000^{* *} \\
(0.000)\end{array}$ & $\begin{array}{l}-0.000^{* *} \\
(0.000)\end{array}$ \\
\hline Partner's income & $\begin{array}{l}0.070^{* * *} \\
(0.017)\end{array}$ & & $\begin{array}{l}0.077^{* * *} \\
(0.017)\end{array}$ & $\begin{array}{l}0.059^{* * *} \\
(0.018)\end{array}$ & $\begin{array}{l}0.069^{* * * *} \\
(0.017)\end{array}$ & $\begin{array}{l}0.055^{* * *} \\
(0.018)\end{array}$ & $\begin{array}{l}0.058^{* * *} \\
(0.018)\end{array}$ \\
\hline Partner's income squ. & $\begin{array}{l}-0.007^{* * *} \\
(0.002)\end{array}$ & & $\begin{array}{l}-0.008^{* * *} \\
(0.002)\end{array}$ & $\begin{array}{l}-0.006^{* * *} \\
(0.002)\end{array}$ & $\begin{array}{l}-0.007 * * * \\
(0.002)\end{array}$ & $\begin{array}{l}-0.006 * * * \\
(0.002)\end{array}$ & $\begin{array}{l}-0.006 * * * \\
(0.002)\end{array}$ \\
\hline Partner's years of education & $\begin{array}{l}0.011 * * * \\
(0.004)\end{array}$ & & $\begin{array}{c}-0.003 \\
(0.004)\end{array}$ & $\begin{array}{c}0.000 \\
(0.004)\end{array}$ & $\begin{array}{l}0.009^{* *} \\
(0.004)\end{array}$ & $\begin{array}{c}0.001 \\
(0.005)\end{array}$ & $\begin{array}{c}0.002 \\
(0.005)\end{array}$ \\
\hline Protestant & Ref. & & Ref. & Ref. & Ref. & Ref. & Ref. \\
\hline Catholic & $\begin{array}{l}0.024 \\
(0.026)\end{array}$ & & $\begin{array}{c}0.020 \\
(0.031)\end{array}$ & $\begin{array}{c}0.014 \\
(0.031)\end{array}$ & $\begin{array}{c}0.027 \\
(0.026)\end{array}$ & $\begin{array}{c}0.017 \\
(0.030)\end{array}$ & $\begin{array}{c}0.019 \\
(0.030)\end{array}$ \\
\hline Other religion & $\begin{array}{l}-0.089^{* *} \\
(0.042)\end{array}$ & & $\begin{array}{c}0.050 \\
(0.058)\end{array}$ & $\begin{array}{c}0.080 \\
(0.058)\end{array}$ & $\begin{array}{l}-0.068 \\
(0.044)\end{array}$ & $\begin{array}{c}0.089 \\
(0.057)\end{array}$ & $\begin{array}{c}0.093 \\
(0.057)\end{array}$ \\
\hline No religion & $\begin{array}{l}0.071 * * * \\
(0.026)\end{array}$ & & $\begin{array}{l}0.064^{* *} \\
(0.031)\end{array}$ & $\begin{array}{c}0.050 \\
(0.032)\end{array}$ & $\begin{array}{l}0.073^{* * *} \\
(0.026)\end{array}$ & $\begin{array}{c}0.052 \\
(0.032)\end{array}$ & $\begin{array}{c}0.056^{*} \\
(0.031)\end{array}$ \\
\hline Married & $\begin{array}{l}-0.238^{* * * *} \\
(0.024)\end{array}$ & & $\begin{array}{l}-0.226^{* * *} \\
(0.024)\end{array}$ & $\begin{array}{l}-0.117^{* * *} \\
(0.025)\end{array}$ & $\begin{array}{l}-0.238^{* * *} \\
(0.024)\end{array}$ & $\begin{array}{l}-0.115^{* * *} \\
(0.025)\end{array}$ & $\begin{array}{l}-0.118^{* * *} \\
(0.025)\end{array}$ \\
\hline Women's age & & $\begin{array}{c}0.011 \\
(0.010)\end{array}$ & $\begin{array}{c}0.007 \\
(0.013)\end{array}$ & $\begin{array}{l}0.039^{* * *} \\
(0.014)\end{array}$ & & $\begin{array}{l}0.038^{* * *} \\
(0.014)\end{array}$ & $\begin{array}{l}0.039 * * * \\
(0.014)\end{array}$ \\
\hline Women's age squ. & & $\begin{array}{c}-0.000 \\
(0.000)\end{array}$ & $\begin{array}{c}-0.000 \\
(0.000)\end{array}$ & $\begin{array}{l}-0.001 * * * \\
(0.000)\end{array}$ & & $\begin{array}{l}-0.001 * * * \\
(0.000)\end{array}$ & $\begin{array}{l}-0.001 * * * \\
(0.000)\end{array}$ \\
\hline Women's years of education & & $\begin{array}{l}0.024^{* * *} \\
(0.004)\end{array}$ & $\begin{array}{l}0.027^{* * *} \\
(0.004)\end{array}$ & $\begin{array}{l}0.028^{* * *} \\
(0.005)\end{array}$ & & $\begin{array}{l}0.030^{* * *} \\
(0.005)\end{array}$ & $\begin{array}{l}0.031 * * * \\
(0.005)\end{array}$ \\
\hline $\begin{array}{l}\text { Protestant } \\
\text { Catholic }\end{array}$ & & $\begin{array}{c}\text { Ref. } \\
0.009\end{array}$ & $\begin{array}{c}\text { Ref. } \\
0.006\end{array}$ & $\begin{array}{l}\text { Ref. } \\
0.014\end{array}$ & & $\begin{array}{l}\text { Ref. } \\
0.011\end{array}$ & $\begin{array}{l}\text { Ref. } \\
0.013\end{array}$ \\
\hline Other religion & & $\begin{array}{l}(0.025) \\
-0.151^{* * *} \\
(0.043)\end{array}$ & $\begin{array}{l}(0.028) \\
-0.160 * * \\
(0.064)\end{array}$ & $\begin{array}{l}(0.029) \\
-0.164 * * \\
(0.065)\end{array}$ & & $\begin{array}{l}(0.028) \\
-0.175^{* * *} \\
(0.064)\end{array}$ & $\begin{array}{l}(0.028) \\
-0.179^{* * *} \\
(0.063)\end{array}$ \\
\hline No religion & & $\begin{array}{l}0.065^{* *} \\
(0.026)\end{array}$ & $\begin{array}{c}(0.004) \\
0.010 \\
(0.032)\end{array}$ & $\begin{array}{c}0.002 \\
(0.034)\end{array}$ & & $\begin{array}{l}-0.002 \\
(0.033)\end{array}$ & $\begin{array}{c}0.002 \\
(0.033)\end{array}$ \\
\hline \# children & & & & $\begin{array}{l}-0.084 * * * \\
(0.011)\end{array}$ & & $\begin{array}{l}-0.086 * * * \\
(0.011)\end{array}$ & $\begin{array}{l}-0.084^{* * * *} \\
(0.011)\end{array}$ \\
\hline \# children $\geq 6$ years & & & & $\begin{array}{l}-0.155^{* * *} \\
(0.014)\end{array}$ & & $\begin{array}{l}-0.155^{* * *} \\
(0.014)\end{array}$ & $\begin{array}{l}-0.157^{* * *} \\
(0.014)\end{array}$ \\
\hline$<20,000$ inhabitants & & & & $\begin{array}{c}0.000 \\
(0.000)\end{array}$ & & $\begin{array}{c}0.000 \\
(0.000)\end{array}$ & $\begin{array}{c}0.000 \\
(0.000)\end{array}$ \\
\hline 20,000-100,000 inhabitants & & & & $\begin{array}{c}0.023 \\
(0.024)\end{array}$ & & $\begin{array}{c}0.027 \\
(0.024)\end{array}$ & $\begin{array}{c}0.028 \\
(0.026)\end{array}$ \\
\hline$>100,000$ inhabitants & & & & $\begin{array}{l}-0.004 \\
(0.028)\end{array}$ & & $\begin{array}{c}0.003 \\
(0.027)\end{array}$ & $\begin{array}{c}0.009 \\
(0.041)\end{array}$ \\
\hline Father-in-law primary education & & & & & Ref. & Ref. & Ref. \\
\hline Father-in-law secondary education & & & & & $\begin{array}{l}-0.080 \\
(0.057)\end{array}$ & $\begin{array}{l}-0.063 \\
(0.061)\end{array}$ & $\begin{array}{l}-0.065 \\
(0.061)\end{array}$ \\
\hline Father-in-law tertiary education & & & & & $\begin{array}{l}-0.106^{*} \\
(0.061)\end{array}$ & $\begin{array}{l}-0.091 \\
(0.063)\end{array}$ & $\begin{array}{l}-0.091 \\
(0.063)\end{array}$ \\
\hline Mother-in-law primary education & & & & & Ref. & Ref. & Ref. \\
\hline Mother-in-law secondary education & & & & & $\begin{array}{c}0.111^{*} \\
(0.059)\end{array}$ & $\begin{array}{c}0.059 \\
(0.054)\end{array}$ & $\begin{array}{c}0.069 \\
(0.054)\end{array}$ \\
\hline Mother-in-law tertiary education & & & & & $\begin{array}{l}0.145^{* *} \\
(0.063)\end{array}$ & $\begin{array}{l}0.098^{*} \\
(0.058)\end{array}$ & $\begin{array}{c}0.108^{*} \\
(0.059)\end{array}$ \\
\hline Father-in-law job prestige & & & & & $\begin{array}{l}0.000 \\
(0.000)\end{array}$ & $\begin{array}{l}-0.000 \\
(0.000)\end{array}$ & $\begin{array}{l}-0.000 \\
(0.000)\end{array}$ \\
\hline Father primary education & & & & & & Ref. & Ref. \\
\hline Father secondary education & & & & & & $\begin{array}{c}0.032 \\
(0.070)\end{array}$ & $\begin{array}{c}0.022 \\
(0.070)\end{array}$ \\
\hline Father tertiary education & & & & & & $\begin{array}{c}0.004 \\
(0.072)\end{array}$ & $\begin{array}{l}-0.006 \\
(0.072)\end{array}$ \\
\hline Mother primary education & & & & & & Ref. & Ref. \\
\hline Mother secondary education & & & & & & $\begin{array}{l}-0.028 \\
(0.056)\end{array}$ & $\begin{array}{l}-0.031 \\
(0.055)\end{array}$ \\
\hline Mother tertiary education & & & & & & $\begin{array}{l}-0.052 \\
(0.059)\end{array}$ & $\begin{array}{l}-0.052 \\
(0.059)\end{array}$ \\
\hline Father job prestige & & & & & & $\begin{array}{c}0.000 \\
(0.000)\end{array}$ & $\begin{array}{c}0.000 \\
(0.000)\end{array}$ \\
\hline Unemployment rate & & & & & & & $\begin{array}{l}0.010^{*} \\
(0.005)\end{array}$ \\
\hline Employment rate & & & & & & & $\begin{array}{l}0.013^{* * *} \\
(0.004)\end{array}$ \\
\hline GDP p.c. & & & & & & & $\begin{array}{l}0.001 \\
(0.001)\end{array}$ \\
\hline Share of foreigners & & & & & & & $\begin{array}{l}-0.003 \\
(0.003)\end{array}$ \\
\hline Size of county & & & & & & & $\begin{array}{l}-0.000 \\
(0.000)\end{array}$ \\
\hline Childcare ratios $<3$ years & & & & & & & $\begin{array}{l}-0.001 \\
(0.002)\end{array}$ \\
\hline Childcare ratios $\geq 3$ years & & & & & & & $\begin{array}{l}-0.001 \\
(0.002)\end{array}$ \\
\hline Observations & 22814 & 22814 & 22814 & 22814 & 22814 & 22814 & 22814 \\
\hline$R$-squared & 0.050 & 0.038 & 0.062 & 0.120 & 0.053 & 0.125 & 0.129 \\
\hline
\end{tabular}

Note: Marginal effects calculated at the mean of the independent variables. Regressions are weighted using provided survey weights. ${ }^{*} p<0.1,{ }^{* *} p<0.05$, *** $p<0.01$.

Source: SOEP v33, Statistisches Bundesamt (2019), own calculation. 
Table A5: Female labour force participation - ALLBUS data

\begin{tabular}{llcccc}
\hline & $(1)$ & $(2)$ & $(3)$ & $(4)$ & $(5)$ \\
\cline { 2 - 6 } Mean of dep. variable & 0.644 & 0.644 & 0.644 & 0.644 & 0.644 \\
\hline Mother-in-law worked & $0.070^{* * *}$ & $0.095^{* * *}$ & $0.090^{* * *}$ & $0.072^{* * *}$ & $0.062^{* * *}$ \\
& $(0.018)$ & $(0.017)$ & $(0.017)$ & $(0.018)$ & $(0.018)$ \\
Controls & & & & & \\
Partner's characteristics & $\mathbb{}$ & & $\checkmark$ & $\checkmark$ & $\checkmark$ \\
Own characteristics & & $\checkmark$ & $\checkmark$ & $\checkmark$ & $\checkmark$ \\
Household characteristics & & & & $\checkmark$ & $\checkmark$ \\
Partner's parents characteristics & & & & & $\checkmark$ \\
Observations & 3525 & 3526 & 3525 & 3525 & 3525 \\
$R$-squared & 0.054 & 0.059 & 0.065 & 0.098 & 0.102 \\
\hline
\end{tabular}

Note: Marginal effects calculated at the mean of the independent variables. See Table A2 for list of control variables. ${ }^{*} p<0.1,{ }^{* *} p<0.05,{ }^{* * *} p<0.01$.

Source: ALLBUS 2000-2016, own calculation. 
Table A6: Heterogeneity by couple characteristics - female labour market outcomes

\begin{tabular}{|c|c|c|c|c|c|c|c|c|}
\hline & \multicolumn{2}{|c|}{ By marital status } & \multicolumn{2}{|c|}{ By marriage duration } & \multicolumn{2}{|c|}{$\begin{array}{l}\text { By years of education } \\
\text { relative to partner }\end{array}$} & \multicolumn{2}{|c|}{$\begin{array}{l}\text { By job prestige of own father } \\
\text { relative to partner's father }\end{array}$} \\
\hline & married & unmarried & $<$ median & $\geq$ median & $\leq$ partner & $>$ partner & $\leq$ partner & $>$ partner \\
\hline Panel A - Labour force participation & (1) & $(2)$ & (3) & (4) & (5) & (6) & (7) & (8) \\
\hline Mother-in-law worked & $\begin{array}{l}0.081^{* * *} \\
(0.026)\end{array}$ & $\begin{array}{c}0.015 \\
(0.028)\end{array}$ & $\begin{array}{c}0.047 \\
(0.029)\end{array}$ & $\begin{array}{c}0.135^{*} \\
(0.077)\end{array}$ & $\begin{array}{l}0.082^{* * *} \\
(0.027)\end{array}$ & $\begin{array}{c}0.054 \\
(0.036)\end{array}$ & $\begin{array}{l}0.085^{* * *} \\
(0.031)\end{array}$ & $\begin{array}{l}0.067^{* *} \\
(0.030)\end{array}$ \\
\hline Own mother worked & $\begin{array}{c}0.032 \\
(0.026)\end{array}$ & $\begin{array}{l}-0.012 \\
(0.027)\end{array}$ & $\begin{array}{c}0.006 \\
(0.027)\end{array}$ & $\begin{array}{l}-0.018 \\
(0.064)\end{array}$ & $\begin{array}{c}0.018 \\
(0.027)\end{array}$ & $\begin{array}{c}0.036 \\
(0.036)\end{array}$ & $\begin{array}{c}0.046 \\
(0.030)\end{array}$ & $\begin{array}{c}0.005 \\
(0.032)\end{array}$ \\
\hline $\begin{array}{l}\text { Observations } \\
\text { Adj. R-squared }\end{array}$ & $\begin{array}{l}19527 \\
0.120\end{array}$ & $\begin{array}{c}3282 \\
0.169\end{array}$ & $\begin{array}{l}5107 \\
0.230\end{array}$ & $\begin{array}{l}1190 \\
0.363\end{array}$ & $\begin{array}{l}15047 \\
0.124\end{array}$ & $\begin{array}{l}7767 \\
0.171\end{array}$ & $\begin{array}{l}12062 \\
0.156\end{array}$ & $\begin{array}{l}10752 \\
0.126\end{array}$ \\
\hline Panel B - Weekly working hours & (1) & $(2)$ & (3) & (4) & $(5)$ & (6) & (7) & (8) \\
\hline $\begin{array}{l}\text { Mother-in-law worked } \\
\text { Own mother worked }\end{array}$ & $\begin{array}{c}1.614^{* *} \\
(0.752) \\
0.920 \\
(0.771)\end{array}$ & $\begin{array}{l}-0.124 \\
(1.019) \\
-0.573 \\
(1.019)\end{array}$ & $\begin{array}{l}1.011 \\
(0.953) \\
-0.246 \\
(0.924)\end{array}$ & $\begin{array}{l}4.922^{* *} \\
(2.133) \\
-1.040 \\
(1.961)\end{array}$ & $\begin{array}{l}2.179^{* * *} \\
(0.827) \\
0.013 \\
(0.840)\end{array}$ & $\begin{array}{c}0.196 \\
(1.077) \\
1.381 \\
(1.063)\end{array}$ & $\begin{array}{l}2.599^{* * *} \\
(0.879) \\
1.412 \\
(0.877)\end{array}$ & $\begin{array}{l}0.821 \\
(0.937) \\
-0.145 \\
(0.991)\end{array}$ \\
\hline Panel C - Log gross monthly labour income & (1) & $(2)$ & (3) & (4) & $(5)$ & (6) & (7) & (8) \\
\hline $\begin{array}{l}\text { Mother-in-law worked } \\
\text { Own mother worked }\end{array}$ & $\begin{array}{l}0.429^{* * *} \\
(0.155) \\
0.388^{* *} \\
(0.155)\end{array}$ & $\begin{array}{l}-0.003 \\
(0.184) \\
-0.038 \\
(0.172)\end{array}$ & $\begin{array}{c}0.214 \\
(0.176) \\
-0.004 \\
(0.159)\end{array}$ & $\begin{array}{c}0.909^{*} \\
(0.466) \\
-0.136 \\
(0.413)\end{array}$ & $\begin{array}{l}0.499^{* * *} \\
(0.167) \\
0.315^{*} \\
(0.166)\end{array}$ & $\begin{array}{c}0.183 \\
(0.220) \\
0.283 \\
(0.216)\end{array}$ & $\begin{array}{l}0.580^{* * *} \\
(0.185) \\
0.544^{* * *} \\
(0.179)\end{array}$ & $\begin{array}{c}0.272 \\
(0.185) \\
0.101 \\
(0.199)\end{array}$ \\
\hline Full set of controls & $\checkmark$ & $\checkmark$ & $\checkmark$ & $\checkmark$ & $\checkmark$ & $\checkmark$ & $\checkmark$ & $\checkmark$ \\
\hline $\begin{array}{l}\text { Observations } \\
\text { Adj. R-squared }\end{array}$ & $\begin{array}{l}19598 \\
0.176\end{array}$ & $\begin{array}{l}3216 \\
0.212\end{array}$ & $\begin{array}{r}5107 \\
0.275\end{array}$ & $\begin{array}{l}1190 \\
0.387\end{array}$ & $\begin{array}{l}15047 \\
0.191\end{array}$ & $\begin{array}{l}7767 \\
0.218\end{array}$ & $\begin{array}{l}12062 \\
0.220\end{array}$ & $\begin{array}{l}10752 \\
0.182\end{array}$ \\
\hline
\end{tabular}

Note: Columns (1) to (8) of Panel A report marginal effects calculated at the mean of the independent variables. See Table A1 for list of control variables. Regressions are weighted using provided survey weights. ${ }^{*} p<0.1,{ }^{* *} p<0.05,{ }^{* * *} p<0.01$.

Source: SOEP v33, Statistisches Bundesamt (2019), own calculation. 
Table A7: Heterogeneity by women's characteristics - female labour market outcomes

\begin{tabular}{|c|c|c|c|c|c|c|c|c|c|}
\hline & \multicolumn{3}{|c|}{ By municipality size (\# Inhabitants) } & \multicolumn{3}{|c|}{ By religion } & \multicolumn{3}{|c|}{ By number of children } \\
\hline & $<20,000$ & $\begin{array}{l}20,000- \\
100,000\end{array}$ & $>100,000$ & $\begin{array}{l}\text { catholic or } \\
\text { protestant }\end{array}$ & $\begin{array}{l}\text { other } \\
\text { religion }\end{array}$ & $\begin{array}{l}\text { no } \\
\text { religion }\end{array}$ & $\begin{array}{c}\text { no } \\
\text { children }\end{array}$ & $\begin{array}{c}1 \text { or } 2 \\
\text { children }\end{array}$ & $\begin{array}{l}3 \text { and more } \\
\text { children }\end{array}$ \\
\hline Panel A - Labour force participation & (1) & $(2)$ & $(3)$ & (4) & (5) & (6) & (7) & (8) & (9) \\
\hline Mother-in-law worked & $\begin{array}{l}0.078^{* *} \\
(0.036)\end{array}$ & $\begin{array}{l}0.108^{* * *} \\
(0.037)\end{array}$ & $\begin{array}{c}0.055 \\
(0.037)\end{array}$ & $\begin{array}{l}0.079 * * * \\
(0.026)\end{array}$ & $\begin{array}{c}0.027 \\
(0.067)\end{array}$ & $\begin{array}{c}0.025 \\
(0.038)\end{array}$ & $\begin{array}{l}0.074^{* * *} \\
(0.025)\end{array}$ & $\begin{array}{l}0.072^{* *} \\
(0.029)\end{array}$ & $\begin{array}{c}0.011 \\
(0.055)\end{array}$ \\
\hline Own mother worked & $\begin{array}{c}0.024 \\
(0.036)\end{array}$ & $\begin{array}{c}0.011 \\
(0.037)\end{array}$ & $\begin{array}{c}0.017 \\
(0.037)\end{array}$ & $\begin{array}{c}0.021 \\
(0.026)\end{array}$ & $\begin{array}{c}0.132^{*} \\
(0.069)\end{array}$ & $\begin{array}{l}-0.003 \\
(0.039)\end{array}$ & $\begin{array}{c}0.003 \\
(0.025)\end{array}$ & $\begin{array}{c}0.036 \\
(0.029)\end{array}$ & $\begin{array}{l}0.119^{* *} \\
(0.051)\end{array}$ \\
\hline Full set of controls & $\checkmark$ & $\checkmark$ & $\checkmark$ & $\checkmark$ & $\checkmark$ & $\checkmark$ & $\checkmark$ & $\checkmark$ & $\checkmark$ \\
\hline $\begin{array}{l}\text { Observations } \\
\text { Adj. R-squared }\end{array}$ & $\begin{array}{l}8763 \\
0.142\end{array}$ & $\begin{array}{c}6702 \\
0.176\end{array}$ & $\begin{array}{l}7349 \\
0.141\end{array}$ & $\begin{array}{l}16917 \\
0.123\end{array}$ & $\begin{array}{l}1897 \\
0.251\end{array}$ & $\begin{array}{l}4000 \\
0.169\end{array}$ & $\begin{array}{c}9423 \\
0.104\end{array}$ & $\begin{array}{l}11201 \\
0.075\end{array}$ & $\begin{array}{l}2190 \\
0.187\end{array}$ \\
\hline Panel B: Weekly working hours & (1) & $(2)$ & (3) & (4) & (5) & (6) & (7) & (8) & (9) \\
\hline Mother-in-law worked & $\begin{array}{c}1.133 \\
(1.098)\end{array}$ & $\begin{array}{l}2.556^{* *} \\
(1.012)\end{array}$ & $\begin{array}{c}0.983 \\
(1.153)\end{array}$ & $\begin{array}{l}1.423^{*} \\
(0.770)\end{array}$ & $\begin{array}{c}1.482 \\
(1.505)\end{array}$ & $\begin{array}{c}0.997 \\
(1.384)\end{array}$ & $\begin{array}{c}1.497^{*} \\
(0.905)\end{array}$ & $\begin{array}{c}1.592^{*} \\
(0.831)\end{array}$ & $\begin{array}{c}0.419 \\
(1.403)\end{array}$ \\
\hline Own mother worked & $\begin{array}{c}0.821 \\
(1.111)\end{array}$ & $\begin{array}{l}-0.165 \\
(0.987)\end{array}$ & $\begin{array}{c}0.455 \\
(1.170)\end{array}$ & $\begin{array}{c}0.620 \\
(0.776)\end{array}$ & $\begin{array}{c}3.693^{* *} \\
(1.744)\end{array}$ & $\begin{array}{l}-0.401 \\
(1.486)\end{array}$ & $\begin{array}{c}0.551 \\
(0.924)\end{array}$ & $\begin{array}{c}0.699 \\
(0.822)\end{array}$ & $\begin{array}{l}4.077^{* * *} \\
(1.443)\end{array}$ \\
\hline Full set of controls & $\checkmark$ & $\checkmark$ & $\checkmark$ & $\checkmark$ & $\checkmark$ & $\checkmark$ & $\checkmark$ & $\checkmark$ & $\checkmark$ \\
\hline $\begin{array}{l}\text { Observations } \\
\text { Adj. R-squared }\end{array}$ & $\begin{array}{l}7653 \\
0.259\end{array}$ & $\begin{array}{c}5921 \\
0.318\end{array}$ & $\begin{array}{r}6339 \\
0.275\end{array}$ & $\begin{array}{l}14760 \\
0.245\end{array}$ & $\begin{array}{l}1723 \\
0.386\end{array}$ & $\begin{array}{r}3430 \\
0.272\end{array}$ & $\begin{array}{l}8229 \\
0.194\end{array}$ & $\begin{array}{c}9757 \\
0.134\end{array}$ & $\begin{array}{l}1927 \\
0.220\end{array}$ \\
\hline Panel C: Log gross monthly labour income & (1) & $(2)$ & (3) & (4) & $(5)$ & (6) & $(7)$ & (8) & (9) \\
\hline Mother-in-law worked & $\begin{array}{c}0.324 \\
(0.220)\end{array}$ & $\begin{array}{l}0.543^{* *} \\
(0.214)\end{array}$ & $\begin{array}{c}0.346 \\
(0.229)\end{array}$ & $\begin{array}{l}0.419^{* * *} \\
(0.158)\end{array}$ & $\begin{array}{c}0.003 \\
(0.323)\end{array}$ & $\begin{array}{c}0.235 \\
(0.255)\end{array}$ & $\begin{array}{c}0.367^{* *} \\
(0.167)\end{array}$ & $\begin{array}{l}0.436^{* *} \\
(0.191)\end{array}$ & $\begin{array}{c}0.161 \\
(0.371)\end{array}$ \\
\hline Own mother worked & $\begin{array}{c}0.343 \\
(0.220)\end{array}$ & $\begin{array}{c}0.145 \\
(0.203)\end{array}$ & $\begin{array}{c}0.350 \\
(0.235)\end{array}$ & $\begin{array}{c}0.290^{*} \\
(0.159)\end{array}$ & $\begin{array}{l}1.100^{* * *} \\
(0.344)\end{array}$ & $\begin{array}{l}0.097 \\
(0.261)\end{array}$ & $\begin{array}{c}0.174 \\
(0.169)\end{array}$ & $\begin{array}{c}0.433^{* *} \\
(0.190)\end{array}$ & $\begin{array}{l}0.866^{* *} \\
(0.357)\end{array}$ \\
\hline Full set of controls & $\checkmark$ & $\checkmark$ & $\checkmark$ & $\checkmark$ & $\checkmark$ & $\checkmark$ & $\checkmark$ & $\checkmark$ & $\checkmark$ \\
\hline Observations & 8763 & 6702 & 7349 & 16917 & 1897 & 4000 & 9423 & 11201 & 2190 \\
\hline Adj. R-squared & 0.183 & 0.241 & 0.208 & 0.171 & 0.328 & 0.201 & 0.142 & 0.108 & 0.200 \\
\hline
\end{tabular}

Note: Columns (1) to (9) of Panel A report marginal effects calculated at the mean of the independent variables. See Table A1 for list of control variables.

Regressions are weighted using provided survey weights. ${ }^{*} p<0.1,{ }^{* *} p<0.05,{ }^{* * *} p<0.01$.

Source: SOEP v33, Statistisches Bundesamt (2019), own calculation. 
Table A8: Sensitivity checks

\begin{tabular}{|c|c|c|c|c|c|c|c|c|}
\hline \multirow[b]{2}{*}{ Panel A: Labour force participation } & \multicolumn{2}{|c|}{$\begin{array}{l}\text { Controlling for } \\
\text { age fixed effects }\end{array}$} & \multicolumn{2}{|c|}{$\begin{array}{c}\text { Inverse probability } \\
\text { weighting }\end{array}$} & \multicolumn{2}{|c|}{$\begin{array}{l}\text { Age restriction } \\
\text { partner }\end{array}$} & \multicolumn{2}{|c|}{$\begin{array}{c}\text { Living in West } \\
\text { Germany in } 1989\end{array}$} \\
\hline & (1) & (2) & (3) & (4) & $(5)$ & (6) & (7) & (8) \\
\hline Mother-in-law worked & $\begin{array}{l}0.072^{* * *} \\
(0.022)\end{array}$ & $\begin{array}{l}0.073^{* * *} \\
(0.022)\end{array}$ & $\begin{array}{l}0.066^{* * *} \\
(0.018)\end{array}$ & $\begin{array}{l}0.059^{* * *} \\
(0.019)\end{array}$ & $\begin{array}{l}0.087^{* * *} \\
(0.024)\end{array}$ & $\begin{array}{l}0.085^{* * *} \\
(0.025)\end{array}$ & $\begin{array}{l}0.072^{* * *} \\
(0.023)\end{array}$ & $\begin{array}{l}0.075^{* * *} \\
(0.023)\end{array}$ \\
\hline Own mother worked & & $\begin{array}{c}0.025 \\
(0.023)\end{array}$ & & $\begin{array}{c}0.025 \\
(0.019)\end{array}$ & & $\begin{array}{c}0.030 \\
(0.025)\end{array}$ & & $\begin{array}{c}0.026 \\
(0.023)\end{array}$ \\
\hline Full set of controls & $\checkmark$ & $\checkmark$ & $\checkmark$ & $\checkmark$ & $\checkmark$ & $\checkmark$ & $\checkmark$ & $\checkmark$ \\
\hline $\begin{array}{l}\text { Observations } \\
R \text {-squared }\end{array}$ & $\begin{array}{c}22814 \\
0.050\end{array}$ & $\begin{array}{c}22814 \\
0.130\end{array}$ & $\begin{array}{c}22814 \\
0.054\end{array}$ & $\begin{array}{l}22814 \\
0.130\end{array}$ & $\begin{array}{l}16122 \\
0.058\end{array}$ & $\begin{array}{l}16122 \\
0.153\end{array}$ & $\begin{array}{r}21666 \\
0.052\end{array}$ & $\begin{array}{c}21666 \\
0.132\end{array}$ \\
\hline Panel B: Weekly working hours & (1) & $(2)$ & (3) & (4) & $(5)$ & (6) & $(7)$ & (8) \\
\hline Mother-in-law worked & $\begin{array}{l}1.874^{* *} \\
(0.740)\end{array}$ & $\begin{array}{l}1.478^{* *} \\
(0.683)\end{array}$ & $\begin{array}{l}1.866^{* * *} \\
(0.637)\end{array}$ & $\begin{array}{l}1.355^{* *} \\
(0.592)\end{array}$ & $\begin{array}{l}2.179 * * * \\
(0.809)\end{array}$ & $\begin{array}{l}1.731^{* *} \\
(0.709)\end{array}$ & $\begin{array}{l}1.752^{* *} \\
(0.754)\end{array}$ & $\begin{array}{l}1.475^{* *} \\
(0.694)\end{array}$ \\
\hline Own mother worked & & & & $\begin{array}{c}0.260 \\
(0.599)\end{array}$ & & $\begin{array}{c}0.203 \\
(0.731)\end{array}$ & & $\begin{array}{c}0.509 \\
(0.705)\end{array}$ \\
\hline Full set of controls & $\checkmark$ & $\checkmark$ & $\checkmark$ & $\checkmark$ & $\checkmark$ & $\checkmark$ & $\checkmark$ & $\checkmark$ \\
\hline Observations & 19913 & 19913 & 19913 & 19913 & 14208 & 14208 & 18870 & 18870 \\
\hline$R$-squared & 0.111 & 0.262 & 0.111 & 0.256 & 0.134 & 0.314 & 0.112 & 0.261 \\
\hline Panel C: Log gross monthly labour income & (1) & $(2)$ & $(3)$ & $(4)$ & (5) & (6) & (7) & (8) \\
\hline Mother-in-law worked & $0.449 * * *$ & $\begin{array}{l}0.391^{* * * *} \\
(0.138)\end{array}$ & $\begin{array}{l}k^{k} 0.401^{* * * *} \\
(0.122)\end{array}$ & $\begin{array}{l}0.306^{* * *} \\
(0.119)\end{array}$ & $\begin{array}{l}0.576^{* * *} \\
(0.161)\end{array}$ & $\begin{array}{l}0.483^{* * *} \\
(0.147)\end{array}$ & $\begin{array}{l}0.440^{* * *} \\
(0.151)\end{array}$ & $\begin{array}{l}0.392^{* * *} \\
(0.141)\end{array}$ \\
\hline Own mother worked & & $\begin{array}{l}0.322^{* *} \\
(0.139)\end{array}$ & & $\begin{array}{l}0.250^{* *} \\
(0.117)\end{array}$ & & $\begin{array}{c}0.299^{* *} \\
(0.149)\end{array}$ & & $\begin{array}{l}0.319^{* *} \\
(0.141)\end{array}$ \\
\hline Full set of controls & $\checkmark$ & $\checkmark$ & $\checkmark$ & $\checkmark$ & $\checkmark$ & $\checkmark$ & $\checkmark$ & $\checkmark$ \\
\hline Observations & 22814 & 22814 & 22814 & 22814 & 16122 & 16122 & 21666 & 21666 \\
\hline$R$-squared & 0.077 & 0.188 & 0.079 & 0.184 & 0.089 & 0.217 & 0.079 & 0.191 \\
\hline
\end{tabular}

Note: Columns (1) to (8) of Panel A report marginal effects evaluated at the mean of the independent variables. See Table A1 for list of control variables. Columns (1) and (2) control for age fixed effects instead of using age linearly and squared as control variables. Regressions are weighted using provided survey weights. ${ }^{*} p<0.1,{ }^{* *} p<0.05,{ }^{* * *} p<0.01$.

Source: SOEP v33, Statistisches Bundesamt (2019), own calculation. 